\title{
14. MIOCENE TO PLEISTOCENE PLANKTONIC FORAMINIFER BIOSTRATIGRAPHY OF THE LAU BASIN AND TONGAN PLATFORM, LEG $135^{1}$
}

\author{
George C.H. Chaproniere ${ }^{2}$ and Hiroshi Nishi $^{3}$
}

\begin{abstract}
Diverse and well-preserved planktonic foraminifers were recovered from six sites (834-839) drilled in the Lau Basin. Planktonic faunas from the Tongan Platform sites varied from those of the Lau Basin sites by being less well preserved (Site 840) to being very poorly preserved and very sparse (Site 841); at Site 841 most samples were barren.

All sites penetrated a volcaniclastic sequence in which thick ash beds were encountered; foraminifer populations within the ash beds were often very small, making it difficult to obtain biostratigraphic data. No hiatuses were encountered in the upper Miocene to Pleistocene sections of the Lau Basin, but a possible break occurs at Site 840 on the Tongan Platform. Site 834 penetrated through a Quaternary-Pliocene sequence overlying basaltic basement, and topmost Miocene (Zone N17B) sediments interbedded within the volcanic sequence. Site 835 penetrated into the lower Pliocene (Zones N19 to N19-20). Site 836 penetrated the shortest section, with Zone N22 (Globorotalia (Truncorotalia) crassaformis hessi Subzone) directly overlying basalts. Site 837 penetrated into the basal part of Zone N22 (Globigerinoides quadrilobatus fistulosus Subzone) overlying basalt. Site 838 failed to encounter basalts, with the oldest sediment being from Zone N22 (Globigerinoides quadrilobatus fistulosus Subzone). Site 839, within the same basin as Site 838, located Zone N22 (Globigerinoides quadrilobatus fistulosus Subzone) sediments directly overlying igneous basement. Site 840 penetrated into the upper Miocene Zone N17A without encountering any major unconformity. Site 841, studied mainly from core-catcher samples, penetrated a Quaternary to questionable upper Miocene sequence that was in fault contact with middle Miocene (Zones N8 to N9) sediments.

For the Lau Basin sites, reworking was encountered only in Sites 834 and 835. Site 834 was drilled adjacent to the Lau Ridge, on which are developed numerous reefal and shallow-water environments, where erosional conditions could have been expected during sea-level lowstands. Site 835 was drilled in a narrow basin that has been remote from these erosional influences; slumping and erosion of material from the adjacent basin slopes appears to have been the source of the reworking.

For the Tongan Platform sites, reworking was observed only in the lower part of the upper Miocene section at Site 841, where late Eocene larger foraminifers are present in conglomerates and grits. The presence of Globorotalia (Globorotalia) multicamerata and small specimens of Sphaeroidinellopsis spp. in the Pleistocene of Site 840 may indicate reworking, but this is not clear.

Unit I, which marks a reduction in volcanic activity in the Lau Basin, ranges in age from the lower part of Zone N22 (Globigerinoides quadrilobatus fistulosus Subzone) at Sites 834 and 835, to within Zone N22 (Globorotalia crassaformis hessi Subzone) at Sites 836 to 838, and within the upper part of Zone N22 (Bolliella praeadamsi Subzone) at Site 839. Units II and III are generally represented by thick to very thick ash beds, which generally contain low-diversity and often poorly preserved assemblages. Igneous sources seem to have remained important contributors of sediment up to the present day.
\end{abstract}

\section{INTRODUCTION}

This paper discusses the results of biostratigraphic studies conducted on six sites (Sites 834-839) in the Lau Basin and two on the Tongan Platform (Sites 840 and 841) (Fig. 1). The studies were hampered by low core recovery and by poor faunas in parts of the sequence, a result of the presence of thick, unconsolidated ash beds. Also, assemblages from within the ash beds often showed dissolution effects. Biostratigraphic study of the upper Miocene to Pleistocene sequence in Site 841 was severely hampered by dissolution (presently in excess of $4800 \mathrm{~m}$ water depth), indicating that the site has been below, or close to, the calcium carbonate compensation depth (CCD) since the late Miocene, at least. Biostratigraphic studies of the upper lower to lower middle Miocene part of the section at Site 841 was also hampered by the well-cemented nature of the sediments; study of this interval is confined to core-catcher samples. The upper Eocene and lower Oligocene succession has been studied separately (Nishi and Chaproniere, this volume; Chaproniere, this volume).

No stable isotope analyses were made on the sections drilled during Leg 135, but magnetostratigraphic studies were made on all sections with varying results (Sager and Abrahamsen, this volume).

\footnotetext{
'Hawkins, J., Parson, L., Allan, J., et al., 1994. Proc. ODP, Sci. Results, 135: College Station, TX (Ocean Drilling Program).

${ }^{2}$ Marine Geoscience Program, Australian Geological Survey Organisation, P.O. Box 378, Canberra, A.C.T. 2601, Australia.

${ }^{3}$ Department of Earth Sciences, Yamagata University, Yamagata, 990, Japan.
}

All samples were prepared using standard techniques, being washed over a $63-\mu \mathrm{m}$ sieve. Wherever possible, all figured specimens were obtained from assemblages at the extremes of their stratigraphic range. These figured specimens, which are designated by numbers prefixed by CPC, are stored in the Commonwealth Palaeontological Collection, Australian Geological Survey Organisation, Canberra, Australia; the remaining specimens are housed in the collections of the Department of Earth Sciences, Yamagata University, Yamagata, Japan.

\section{PREVIOUS WORK}

Kennett (1973) listed the planktonic foraminifer faunas from Deep Sea Drilling Project (DSDP) Site 203 in the Lau Basin, southwest of Sites 838 and 839 . The basal sediments were assigned to Zones N20 (approximately N19-20 in current usage), and N21 to N23.

During 1982 and 1984 two cruises by the S.P. Lee were made over the southern Tongan Platform and part of the Lau Ridge. These resulted in a number of successful dredging operations. Eight dredge stations were occupied within $50 \mathrm{~km}$ of Site 840 , and three within 60 $\mathrm{km}$ of Site 841. Biostratigraphic studies using planktonic foraminifers were made on these samples by Chaproniere (1985a, 1985b, in press $\mathrm{a}$, in press $\mathrm{b}$ ). The results of these studies indicated that assemblages from Zones N17A to N22 (Globorotalia (Truncorotalia) crassaformis hessi Subzone) were present on the southern Tongan Platform; the rarity of samples from Zone N18 was related to the short time span of this zone and the rarity of samples from Zone N21 was attributed to a possible hiatus within this interval. Lithoclasts with late Eocene 


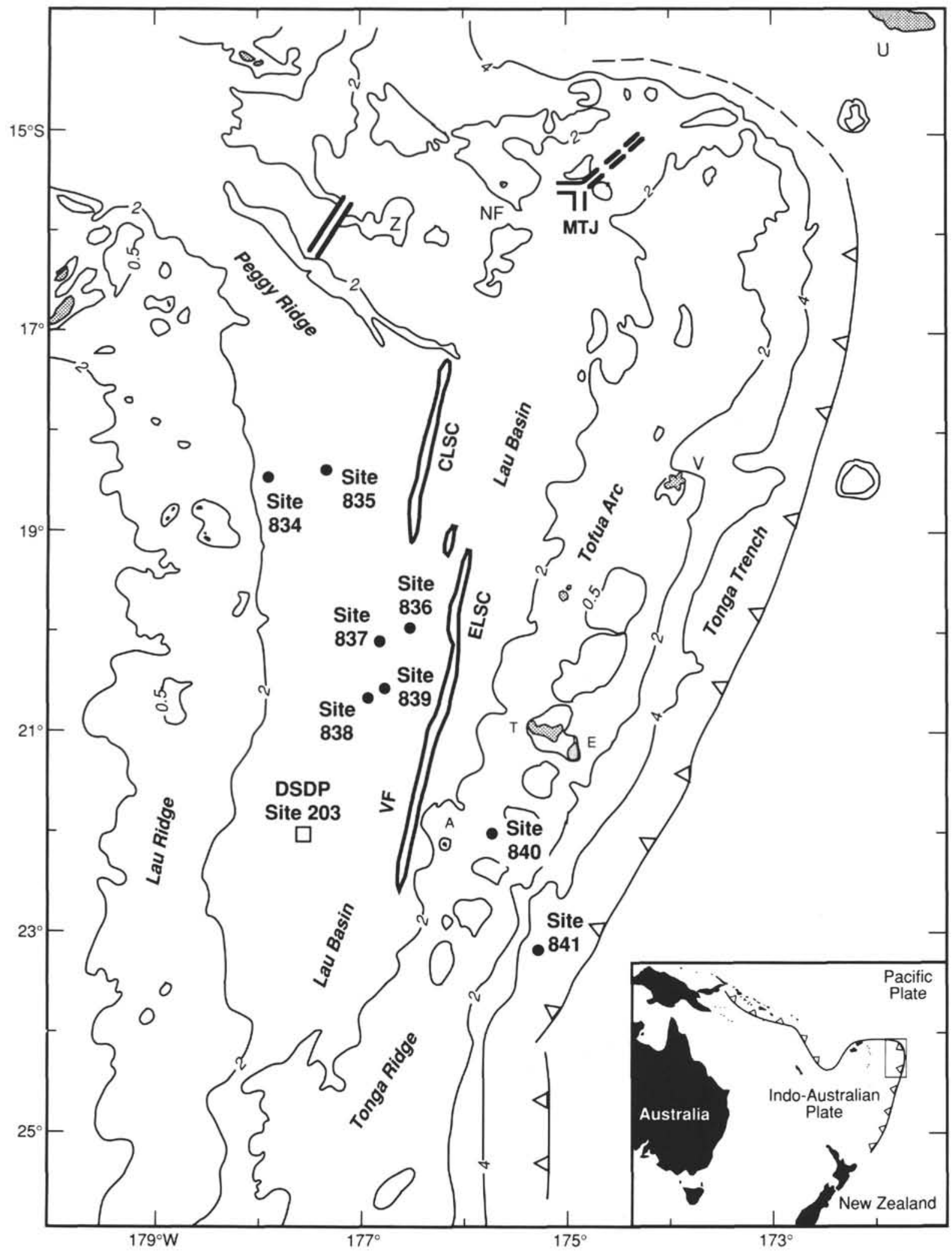

Figure 1. Map showing the bathymetry (in kilometers) and the locations of Sites 834-841 (after Hawkins, Parson, Allan, et al., 1992). $\mathrm{CLSC}=$ Central Lau Spreading Center, ELSC = Eastern Lau Spreading Center, MTJ = Mangatolu Triple Junction, VF = Valu Fa Ridge, and $\mathrm{Z}=$ Zephyr Shoal. Islands include 'Ata (A), 'Eua (E), Niuafo'ou (NF), Tongatapu (T), Vava'u (V), and Upolu (U). 
planktonic faunas were found in some samples from the eastern side of the platform (Chaproniere, in press b). The Lau Ridge sites sampled sediments from Zones N4A, N17 (probably N17B), N22, and N23 (Chaproniere, in press a).

Hayward (1985) made a study of planktonic foraminifers from samples from gravity and piston cores, and dredges gathered on Cruise Natsushima 84 from the Lau Basin and northern part of the Tongan Platform. Hayward (1985) found late Miocene and younger (the majority being Pliocene and Pleistocene) assemblages from the dredge samples, and Zones N21 to N23 faunas were recovered from two piston cores. No faunal listings were given, making it impossible to compare these faunas with those from Leg 135.

Daniels (1990) based a study on a piston core (Sonne, Cruise SO35) taken in the Lau Basin southwest of Sites 838 and 839. Though no biostratigraphic zonation was applied to the core, the fauna from the lower part of the hole contained $G$. (T.) crassaformis hessi, with $G$. (T.) truncatulinoides, but without $G$. (T.) tosaensis; this is typical of Zone N22 (Globorotalia (Truncorotalia) crassaformis hessi Subzone).

\section{PLANKTONIC FORAMINIFER SUCCESSION}

The distribution of all planktonic taxa recorded from all of the sections studied is given in Tables 1-7, and 9. For convenience, the distribution charts for the two or three holes at each site (A, B or C) have been combined into a single table; the samples have been assigned to their relative positions at each site and are prefixed by either A, B, or C. Some of the important taxa are illustrated in Plates $1-4$. In the following discussion, only the ranges of biostratigraphically significant taxa are discussed.

\section{Site 834}

Site 834 was drilled adjacent to the Lau Ridge (Fig. 1). The sequence was divided into three units (Units I-III) based on the volcaniclastic content of the sediments; ash beds were found to be thicker and more numerous toward the base of the section (Hawkins, Parson, Allan, et al., 1992). Unit III directly overlies a basaltic sequence, the upper part of which contains interbedded sediment horizons that were found to contain low-diversity faunas.

The lowest samples (Table 1) with planktonic foraminifers from sediments interbedded within the basaltic sequence (Samples 135834B-37R-CC, -37R-1, 122-127 cm, and -37R-1, 104-108 cm) contain Globorotalia (Globorotalia) tumida plesiotumida and G. (Obandyella) margaritae without $G$. (G.) tumida tumida. $G$. (G.) cultrata limbata, dextrally coiled $G$. $(G$. ) cultrata menardii, first appear in Sample 135-834B-37R-1, 122-127 cm, continuing to Sample 135-834A$5 \mathrm{H}-1,110-114 \mathrm{~cm}$. Pulleniatina primalis, $G$. (G.) multicamerata, and Dentoglobigerina altispira altispira first appear in Sample 135-834B37R-1, 104-108 cm. G. (G.) tumida tumida appears in Sample 135834B-13R-CC, in samples from within the upper part of the basaltic sequence. P. praecursor ranges from Sample 135-834A-16X-1, 74-76 $\mathrm{cm}$, near the base of the sedimentary sequence to Sample 135-834A$8 \mathrm{H}-4,39-42 \mathrm{~cm}$. Sphaeroidinella dehiscens appears in Sample 135834B-6R-CC, and $P$. obliquiloculata in Sample 135-834A-11X-CC. $G$. (Truncorotalia) crassaformis crassaformis is found from Sample 135-834A-11H-1, 63-67 cm, and G. (T.) tosaensis from Sample 135$834 \mathrm{~A}-7 \mathrm{H}-4,99-102 \mathrm{~cm}$; the last occurrence (LO) of $G$. (O.) margaritae is in Sample 135-834A-8H-4, 39-42 cm. Globigerinoides quadrilobatus fistulosus occurs between Samples 135-834A-7H-1, 55-59 $\mathrm{cm}$, to $-4 \mathrm{H}-6,120-124 \mathrm{~cm}$; the presence of this species and other older forms in the upper part of this site is ascribed to reworking.

The first appearance (FA) of $G$. (T.) truncatulinoides is in Sample 135-834A-6H-5, 98-102 cm. The pink form of Globigerinoides ruber is found from Sample 135-834A-4H-2, 80-84 cm, followed by $G$. (T.) crassaformis hessi in Sample 135-834A-3H-4, 15-20 cm, and Bolliella praeadamsi in Sample 135-834A-1H-3, 96-100 cm. Globigerina (Globoturborotalita) decoraperta ranges to Sample 135-
Table 1. Distribution chart, Site 834.

\begin{tabular}{|c|c|c|}
\hline \multicolumn{2}{|r|}{ Biostratigraphy } & \multirow[t]{2}{*}{ Sample } \\
\hline Zone & Subzone & \\
\hline \multirow{4}{*}{$\mathrm{N} 22$} & Bolliella praeadamsi & \begin{tabular}{|l}
$834 \mathrm{~A}-1 \mathrm{H}-2,20-24$ \\
$834 \mathrm{~A}-1 \mathrm{H}-3,96-100$ \\
\end{tabular} \\
\hline & $\begin{array}{c}\text { Gioborotalia (Truncorotalia) } \\
\text { crassaformis hessi }\end{array}$ & $\begin{array}{l}834 \mathrm{~A}-1 \mathrm{H}-4,100-104 \\
834 \mathrm{~A}-1 \mathrm{H}-5,9-13 \\
834 \mathrm{~A}-1 \mathrm{H}, \mathrm{CC} \\
834 \mathrm{~B}-1 \mathrm{R}, \mathrm{CC} \\
834 \mathrm{~A}-2 \mathrm{H}-2,100-104 \\
834 \mathrm{~A}-2 \mathrm{H}-2,129-134 \\
834 \mathrm{~A}-2 \mathrm{H}-6,22-26 \\
834 \mathrm{~A}-2 \mathrm{H}-6,30-34 \\
834 \mathrm{~A}-2 \mathrm{H}, \mathrm{CC} \\
834 \mathrm{~A}-3 \mathrm{H}-1,96-100 \\
834 \mathrm{~A}-3 \mathrm{H}-1,120-124 \\
834 \mathrm{~A}-3 \mathrm{H}-3,48-53 \\
834 \mathrm{~A}-3 \mathrm{H}-3,140-145 \\
834 \mathrm{~A}-3 \mathrm{H}-4,15-20 \\
\end{array}$ \\
\hline & $\begin{array}{l}\text { Globorotalia (Truncorotalia) } \\
\text { crassaformis viola }\end{array}$ & $\begin{array}{l}834 \mathrm{~A}-3 \mathrm{H}-4,85-90 \\
834 \mathrm{~A}-3 \mathrm{H}-4,120-125 \\
834 \mathrm{~A}-3 \mathrm{H}-6,100-104 \\
834 \mathrm{~A}-3 \mathrm{H}-6,130-134 \\
834 \mathrm{~A}-3 \mathrm{H}, \mathrm{CC} \\
834 \mathrm{~A}-4 \mathrm{H}-1,120-124 \\
834 \mathrm{~A}-4 \mathrm{H}-2,80-84 \\
834 \mathrm{~A}-4 \mathrm{H}-5,35-40 \\
834 \mathrm{~A}-4 \mathrm{H}-5,60-65 \\
\end{array}$ \\
\hline & $\begin{array}{c}\text { Globigerinoides } \\
\text { quadrilobatus fistulosus }\end{array}$ & $\begin{array}{l}834 \mathrm{~A}-4 \mathrm{H}-6,120-124 \\
834 \mathrm{~A}-4 \mathrm{H}-7,20-24 \\
834 \mathrm{~A}-4 \mathrm{H}, \mathrm{CC} \\
834 \mathrm{~A}-5 \mathrm{H}-1,95-99 \\
834 \mathrm{~A}-5 \mathrm{H}-1,110-114 \\
834 \mathrm{~A}-5 \mathrm{H}-6,100-104 \\
834 \mathrm{~A}-5 \mathrm{H}-6,126-130 \\
834 \mathrm{~A}-5 \mathrm{H}, \mathrm{CC} \\
834 \mathrm{~A}-6 \mathrm{H}-1,65-69 \\
834 \mathrm{~A}-6 \mathrm{H}-1,80-84 \\
834 \mathrm{~A}-6 \mathrm{H}-3,51-53 \\
834 \mathrm{~A}-6 \mathrm{H}-5,98-102 \\
\end{array}$ \\
\hline & N21 & \begin{tabular}{|l|}
$834 \mathrm{~A}-6 \mathrm{H}, \mathrm{CC}$ \\
$834 \mathrm{~A}-7 \mathrm{H}-1,55-59$ \\
$834 \mathrm{~A}-7 \mathrm{H}-3,130-135$ \\
$834 \mathrm{~A}-7 \mathrm{H}-4,99-104$ \\
\end{tabular} \\
\hline & $\mathrm{N} 19-20$ & \begin{tabular}{|l}
$834 \mathrm{~A}-7 \mathrm{H}-6,40-45$ \\
$834 \mathrm{~A}-7 \mathrm{H}, \mathrm{CC}$ \\
$834 \mathrm{~A}-8 \mathrm{H}-3,99-104$ \\
$834 \mathrm{~A}-8 \mathrm{H}-4,39-42$ \\
$834 \mathrm{~A}-8 \mathrm{H}-4,53-58$ \\
$834 \mathrm{~A}-8 \mathrm{H}, \mathrm{CC}$ \\
$834 \mathrm{~B}-2 \mathrm{R}, \mathrm{CC}$ \\
$834 \mathrm{~A}-9 \mathrm{H}-1,139-143$ \\
$834 \mathrm{~A}-9 \mathrm{H}-3,18-23$ \\
$834 \mathrm{~A}-9 \mathrm{H}-5,74-78$ \\
$834 \mathrm{~A}-9 \mathrm{H}-6,147-150$ \\
$834 \mathrm{~A}-9 \mathrm{H}, \mathrm{CC}$ \\
$834 \mathrm{~B}-3 \mathrm{R}, \mathrm{CC}$ \\
$834 \mathrm{~A}-10 \mathrm{X}-2,20-25$ \\
$834 \mathrm{~A}-10 \mathrm{X}-2,136-141$ \\
$834 \mathrm{~A}-10 \mathrm{X}-3,50-55$ \\
$834 \mathrm{~A}-10 \mathrm{X}, \mathrm{CC}$ \\
834B-4R,CC \\
$834 \mathrm{~A}-11 \mathrm{X}-1,63-67$ \\
\end{tabular} \\
\hline & N19 & \begin{tabular}{|l} 
834A-11X-1,91-95 \\
834A-11X-2,100-104 \\
834 A-11X-3,71-75 \\
834A-11X,CC \\
$834 \mathrm{~B}-5 \mathrm{R}, \mathrm{CC}$ \\
$834 \mathrm{~A}-12 \mathrm{X}-1,20-24$ \\
$834 \mathrm{~A}-12 \mathrm{X}-1,120-124$ \\
$834 \mathrm{~A}-12 \mathrm{2}-2,35-39$ \\
834A-12X,CC \\
834B-6R,CC \\
\end{tabular} \\
\hline & N18 & \begin{tabular}{|l|}
$834 \mathrm{~A}-13 \mathrm{X}, \mathrm{CC}$ \\
$834 \mathrm{~A}-14 \mathrm{X}, \mathrm{CC}$ \\
834B-7R,CC \\
834A-15X,CC \\
$834 \mathrm{~A}-16 \mathrm{X}-1,74-76$ \\
$834 \mathrm{~A}-16 \mathrm{X}-1,110-115$ \\
834A-16X,CC \\
834A-17X,CC \\
834B-11R,CC \\
834B-13R-2,102-103 \\
834B-13R,CC \\
\end{tabular} \\
\hline & $\mathrm{N} 17 \mathrm{~B}$ & \begin{tabular}{|l|}
$834 \mathrm{~B}-37 \mathrm{R}-1,104-108$ \\
834B-37R-1,122-127 \\
834B-37R,CC \\
834B-43R,CC \\
834B-44R,CC \\
\end{tabular} \\
\hline
\end{tabular}


834A-4H-1, 120-124 cm; some specimens in Sample 135-834A-1H$2,20-24 \mathrm{~cm}$, are probably reworked. No younger forms, such as $B$. calida calida or B. adamsi were found at this site. As noted above, some species have been found higher than previously recorded: Globigerina (Globoturborotalita) decoraperta, $G$. (G.) nepenthes, Globigerinoides obliquus extremus, G. quadrilobatus fistulosus, Globorotalia (Globorotalia) cultrata limbata, $G$. (G.) multicamerata, G. (Truncorotalia) tosaensis, and Sphaeroidinellopsis seminulina have been recorded above the FA of $G$. (T.) crassaformis hessi; these records are attributed to reworking. Pulleniatina populations are mainly sinistrally coiled below Sample 135-834A-9H-1, 139-143 cm, and again between Samples 135-834A-4H-5, 35-40 cm, and -4H-CC.

\section{Site 835}

Site 835 was drilled through the thickest sedimentary sequence of a small isolated basin (Fig. 1). The sequence was divided into two units (I and II) based on the volcaniclastic content of the sediments, with Unit II being made up mainly of ash beds (Hawkins, Parson, Allan, et al., 1992). Unit II directly overlies basaltic basement. Unit I, dominated by foraminifer-nannofossil oozes, was found to contain large amounts of reworked biota, almost certainly derived from Unit II or the basal beds of Unit I. Some parts of the section may be slump blocks. The almost continuous presence of reworked specimens in the upper parts of Unit I indicates that older sediments were being eroded from semiconsolidated material forming the slopes of the basin. These reworked faunas have made it difficult to resolve the biostratigraphy for parts of Unit I, although first appearance events have been able to be used.

The lowest samples of Unit II (Table 2), from the lowest part of Core $135-835 \mathrm{~A}-16 \mathrm{H}$, either contain low-diversity assemblages or were barren. Globigerinoides conglobatus, G. quadrilobatus sacculifer, Sphaeroidinella dehiscens, and Globorotalia (Globorotalia) tumida tumida being the most common taxa at these levels; Globigerinoides obliquus extremus appears in Sample 135-835A-16H-5, $108-113 \mathrm{~cm}$. G. (Truncorotalia) tosaensis, G. (T.) crassaformis crassaformis, and Globigerinoides quadrilobatus fistulosus all appear in Sample 135-832A-16H-2, 103-109 cm. G. (T.) truncatulinoides first appears in Sample 135-835A-15H-2, 130-136 cm. G. (G.) multicamerata, $G$. $(G$.) cultrata limbata and dextrally coiled $G$. (G.) cultrata menardii are common components of the assemblages between samples from Cores $135-835 \mathrm{~A}-16 \mathrm{H}$ to $-11 \mathrm{H}$; these taxa are present also above these levels, but from Sample 135-835A-10H-CC sinistrally coiled specimens of $G$. (G.) cultrata menardii are also present; from this level to the top of the Hole 835A, populations of $G$. $(G$.) cultrata menardii vary from being totally sinistrally coiled, to being of mixed sinistral and dextral forms. G. (T.) crassaformis hessi first appears in Sample 135-835A-6H-6, 40-44 cm, Bolliella praeadamsi in Sample 135-835A-3H-2, 26-30 cm, and B. calida calida in Sample 135$835 \mathrm{~A}-1 \mathrm{H}-1,99-104 \mathrm{~cm}$.

Pink specimens of Globigerinoides ruber first appear in Sample $135-835 \mathrm{~A}-8 \mathrm{H}-3,3-8 \mathrm{~cm}$, but they are absent from samples above this until Sample $135-835 \mathrm{~A}-6 \mathrm{H}-2,30-34 \mathrm{~cm}$; this taxon is present in most samples above this level. Taxa such as Dentoglobigerina altispira altispira, G. obliquus extremus, G. quadrilobatus fistulosus, $G$. (G.) multicamerata, $G$. (G.) cultrata limbata, dextrally coiled $G$. $(G$.) cultrata menardii and Sphaeroidinellopsis spp. are present intermittently throughout the whole sequence; $G$. $(G$.) decoraperta ranges to Sample $135-835 \mathrm{~A}-1 \mathrm{H}-6,52-56 \mathrm{~cm}$. Populations of Pulleniatina spp. that are dominated by sinistrally coiled specimens are found at only a few levels within the interval from Samples 135-835A-10H-1, 101-106 $\mathrm{cm}$, to Sample 135-835A-6H-6, 131-136 cm.

\section{Site 836}

The sequence drilled at Site 836 was the thinnest encountered in this study. Two stratigraphic units have been recognized, Subunits IA and IB, with Subunit IB being dominated by volcaniclastic material
Table 2. Distribution chart, Site 835.

\begin{tabular}{|c|c|c|}
\hline \multicolumn{2}{|r|}{ Biostratigraphy } & \multirow[t]{2}{*}{ Sample } \\
\hline Zone & Subzone & \\
\hline $\mathrm{N} 23$ & Bolliella calida calida & $835 \mathrm{~A}-1 \mathrm{H}-1,99-104$ \\
\hline \multirow[b]{2}{*}{$\mathrm{N} 22$} & Bolliella praeadamsi & \begin{tabular}{|l}
$835 \mathrm{~A}-1 \mathrm{H}-3,62-68$ \\
$835 \mathrm{~A}-1 \mathrm{H}-4,138-143$ \\
$835 \mathrm{~A}-1 \mathrm{H}-6,52-56$ \\
$835 \mathrm{~A}-1 \mathrm{H}, \mathrm{CC}$ \\
$835 \mathrm{~B}-1 \mathrm{R}, \mathrm{CC}$ \\
$835 \mathrm{~A}-2 \mathrm{H}-2,110-115$ \\
$835 \mathrm{~A}-2 \mathrm{H}-4,80-85$ \\
$835 \mathrm{~A}-2 \mathrm{H}-5,110-115$ \\
$835 \mathrm{~A}-2 \mathrm{H}-6,94-96$ \\
$835 \mathrm{~A}-2 \mathrm{H}-6,97-99$ \\
$835 \mathrm{~A}-2 \mathrm{H}, \mathrm{CC}$ \\
$835 \mathrm{~A}-3 \mathrm{H}-1,131-135$ \\
$835 \mathrm{~A}-3 \mathrm{H}-2,26-30$ \\
\end{tabular} \\
\hline & $\begin{array}{l}\text { Globorotalia (Truncorotalia) } \\
\text { crassaformis hessi }\end{array}$ & $\begin{array}{l}835 \mathrm{~A}-3 \mathrm{H}-3,40-46 \\
835 \mathrm{~A}-3 \mathrm{H}-5,99-104 \\
835 \mathrm{~A}-3 \mathrm{H}, \mathrm{CC} \\
835 \mathrm{~A}-4 \mathrm{H}-1,134-138 \\
835 \mathrm{~A}-4 \mathrm{H}-3,30-34 \\
835 \mathrm{~A}-4 \mathrm{H}-4,55-60 \\
835 \mathrm{~A}-4 \mathrm{H}-6,129-133 \\
835 \mathrm{~A}-4 \mathrm{H}, \mathrm{CC} \\
835 \mathrm{~A}-5 \mathrm{H}-1,124-129 \\
835 \mathrm{~A}-5 \mathrm{H}-2,52-57 \\
835 \mathrm{~A}-5 \mathrm{H}-4,40-44 \\
835 \mathrm{~A}-5 \mathrm{H}-6,115-120 \\
835 \mathrm{~A}-5 \mathrm{H}, \mathrm{CC} \\
835 \mathrm{~A}-6 \mathrm{H}-1,40-44 \\
835 \mathrm{~A}-6 \mathrm{H}-2,30-34 \\
835 \mathrm{~A}-6 \mathrm{H}-4,30-34 \\
835 \mathrm{~A}-6 \mathrm{H}-6,40-44 \\
\end{array}$ \\
\hline & crassaformis viola & $\begin{array}{l}835 \mathrm{~A}-6 \mathrm{H} \cdot 6,132-136 \\
835 \mathrm{~A}-6 \mathrm{H}, \mathrm{CC} \\
835 \mathrm{~A}-7 \mathrm{H}-3,120-124 \\
835 \mathrm{~A}-7 \mathrm{H}-4,33-38 \\
835 \mathrm{~A}-7 \mathrm{H}-4,126-130 \\
835 \mathrm{~A}-7 \mathrm{H}-5,52-57 \\
835 \mathrm{~A}-7 \mathrm{H}-6,27-32 \\
835 \mathrm{~A}-7 \mathrm{H}-6,60-64 \\
835 \mathrm{~A}-7 \mathrm{H}-7,25-29 \\
835 \mathrm{~A}-7 \mathrm{H}, \mathrm{CC} \\
835 \mathrm{~A}-8 \mathrm{H}-1,128-132 \\
835 \mathrm{~A}-8 \mathrm{H}-2,98-102 \\
835 \mathrm{~A}-8 \mathrm{H}-3,3-8 \\
835 \mathrm{~A}-8 \mathrm{H}-4,37-45 \\
835 \mathrm{~A}-8 \mathrm{H}, \mathrm{CC} \\
835 \mathrm{~A}-9 \mathrm{H}-2,44-46 \\
835 \mathrm{~A}-9 \mathrm{H}-3,51-55 \\
835 \mathrm{~A}-9 \mathrm{H}-5,143-148 \\
835 \mathrm{~A}-9 \mathrm{H}-7,49-54 \\
835 \mathrm{~A}-9 \mathrm{H}, \mathrm{CC} \\
835 \mathrm{~A}-10 \mathrm{H}-1,101-106 \\
835 \mathrm{~A}-10 \mathrm{H}-4,109-114 \\
835 \mathrm{~A}-10 \mathrm{H}-5,46-50 \\
835 \mathrm{~A}-10 \mathrm{H}-6,5-10 \\
835 \mathrm{~A}-10 \mathrm{H}, \mathrm{CC} \\
835 \mathrm{~A}-11 \mathrm{H}-1,118-123 \\
835 \mathrm{~A}-11 \mathrm{H}-2,33-38\end{array}$ \\
\hline & $\begin{array}{l}\text { Clobigerinoides } \\
\text { quadrilobutus fistulosus }\end{array}$ & $\begin{array}{l}835 \mathrm{~A}-11 \mathrm{H}-5,47-53 \\
835 \mathrm{~A}-11 \mathrm{H}-6,90-95 \\
835 \mathrm{~A}-11 \mathrm{H}, \mathrm{CC} \\
835 \mathrm{~A}-12 \mathrm{H}-1,89-94 \\
835 \mathrm{~A}-12 \mathrm{H}-2,88-94 \\
835 \mathrm{~A}-12 \mathrm{H}-5,81-86 \\
835 \mathrm{~A}-12 \mathrm{H}-6,81-86 \\
835 \mathrm{~A}-12 \mathrm{H}, \mathrm{CC} \\
835 \mathrm{~A}-13 \mathrm{H}-1,110-115 \\
835 \mathrm{~A}-13 \mathrm{H}-3,50-55 \\
835 \mathrm{~A}-13 \mathrm{H}-4,90-95 \\
835 \mathrm{~A}-13 \mathrm{H}-5,86-91 \\
835 \mathrm{~A}-13 \mathrm{H}, \mathrm{CC} \\
835 \mathrm{~A}-14 \mathrm{H}-1,123-127 \\
835 \mathrm{~A}-14 \mathrm{H}-3,65-69 \\
835 \mathrm{~A}-14 \mathrm{H}-5,53-57 \\
835 \mathrm{~A}-14 \mathrm{H}-7,20-24 \\
835 \mathrm{~A}-14 \mathrm{H}, \mathrm{CC} \\
835 \mathrm{~A}-15 \mathrm{H}-2,33-38 \\
835 \mathrm{~A}-15 \mathrm{H}-2,130-136 \\
835 \mathrm{~A}-15 \mathrm{H}-4,13-19 \\
835 \mathrm{~A}-15 \mathrm{H}-7,10-15 \\
835 \mathrm{~A}-15 \mathrm{H}, \mathrm{CC} \\
835 \mathrm{~A}-16 \mathrm{H}-2,39-44 \\
\end{array}$ \\
\hline \multicolumn{2}{|r|}{$\mathrm{N} 21$} & $\begin{array}{l}835 \mathrm{~A}-16 \mathrm{H}-2,103-109 \\
835 \mathrm{~A}-16 \mathrm{H}-5,108-113 \\
835 \mathrm{~A}-16 \mathrm{H}-6,84-89 \\
835 \mathrm{~A}-16 \mathrm{H}, \mathrm{CC} \\
835 \mathrm{~B}-2 \mathrm{R}, \mathrm{CC} \\
835 \mathrm{~A}-17 \mathrm{H}-1,82-87 \\
835 \mathrm{~A}-17 \mathrm{H}-1,128-133 \\
835 \mathrm{~A}-17 \mathrm{H}, \mathrm{CC} \\
835 \mathrm{~A}-18 \mathrm{X}-1,11-13 \\
\end{array}$ \\
\hline & N19-20 & $\begin{array}{l}835 \mathrm{~A}-18 \mathrm{X}-1,44-45 \\
835 \mathrm{~A}-18 \mathrm{X}, \mathrm{CC}\end{array}$ \\
\hline
\end{tabular}


and directly overlies basalt. The upper part of the basaltic sequence has thin sedimentary horizons interbedded with the basalts (Hawkins, Parson, Allan, et al., 1992). These thin beds were either barren of foraminifers or contained low-diversity assemblages. The sediments overlying the basalts contained good to excellent faunas, depending on their ash content.

$G$. (T.) crassaformis hessi occurs from Sample 135-836A-6X-CC (Table 3). Bolliella praeadamsi first appears in Sample 135-836A$2 \mathrm{H}-\mathrm{CC}$ and B. calida calida in Sample 135-836A-1H-CC. Pulleniatina finalis, which is rare, occurs in Samples 135-836A-3H-1, 92-96 $\mathrm{cm}$, and $-1 \mathrm{H}-\mathrm{CC}$; all populations of Pulleniatina spp. are dominated by dextrally coiled individuals. Pink specimens of Globigerinoides ruber are present between Samples 135-836A-3H-6, 48-52 cm, and $-1 \mathrm{H}-1,78-83 \mathrm{~cm}$. No evidence of reworked forms is present at this site. $G$. $(G$.) decoraperta has not been recorded.

\section{Site 837}

The sequence at Site 837 was divided into two main units, Units I and II, on the basis of the distribution of volcaniclastic material; Unit II contained large quantities of volcanic material. Unit II was subdivided into five subunits (A-E) on the basis of grain size, sedimentary structures, and composition (Hawkins, Parson, Allan, et al., 1992). The basalts underlying the sediments lacked interbedded oozes.

Globorotalia (T.) truncatulinoides, $G$. (T.) tosaensis, $G$. (G.) decoraperta, G. obliquus extremus, G. quadrilobatus fistulosus, and Sphaeroidinellopsis paenedehiscens are present in Sample 135-837A-9H-3, $66-70 \mathrm{~cm}$ (Table 4). S. paenedehiscens last occurs in Sample 135837A-9H-1, 121-125 cm, and G. quadrilobatus fistulosus in Sample 135-837A-8H-CC. G. (T.) tosaensis ranges to Sample 135-837A-3H-5, 54-59 cm, and G. (G.) decoraperta in Sample 135-837A-3H-5, 54-59 $\mathrm{cm}$. Pink specimens of $G$. ruber appear in Sample 135-837A-3H-1, 93-99 cm, and G. (T.) crassaformis hessi in Sample 135-837A-2H-4, $118-123 \mathrm{~cm}$; this subspecies last occurs in Sample 135-837A-1H-4, 28-34 cm, with Bolliella praeadamsi first appearing in this sample. As with Site 836, no reworking of older forms is obvious at this site.

\section{Site 838}

At Site 838 the sedimentary sequence was divided into three units. Unit III was the lowest and was characterized by volcanic conglom-

Table 3. Distribution chart, Site 836.

\begin{tabular}{|c|c|c|}
\hline \multicolumn{2}{|r|}{ Biostratigraphy } & \multirow[t]{2}{*}{ Sample } \\
\hline Zone & Subzone & \\
\hline $\mathrm{N} 23$ & Bolliella calida calida & $\begin{array}{l}836 \mathrm{~A}-1 \mathrm{H}-1,12-17 \\
836 \mathrm{~A}-1 \mathrm{H}-1,43-48 \\
836 \mathrm{~A}-1 \mathrm{H}-1,78-83 \\
836 \mathrm{~A}-1 \mathrm{H}-1,98-103 \\
836 \mathrm{~A}-1 \mathrm{H}, \mathrm{CC}\end{array}$ \\
\hline \multirow[b]{2}{*}{$\mathrm{N} 22$} & Bolliella praeadamsi & $\begin{array}{l}836 \text { A-2H-1,98-103 } \\
836 \text { A-2H-3,53-58 } \\
836 \text { A-2H-4,57-62 } \\
836 \text { A-2H-6,46-51 } \\
836 \text { A-2H,CC }\end{array}$ \\
\hline & $\begin{array}{c}\text { Globorotalia (Truncorotalia) } \\
\text { crassaformis hessi }\end{array}$ & $\begin{array}{l}836 \mathrm{~A}-3 \mathrm{H}-1,33-37 \\
836 \mathrm{~A}-3 \mathrm{H}-1,92-96 \\
836 \mathrm{~A}-3 \mathrm{H}-5,126-130 \\
836 \mathrm{~A}-3 \mathrm{H}-6,48-52 \\
836 \mathrm{~A}-3 \mathrm{H}, \mathrm{CC} \\
836 \mathrm{~A}-4 \mathrm{H}-1,2-4 \\
836 \mathrm{~A}-4 \mathrm{H}, \mathrm{CC} \\
836 \mathrm{~A}-5 \mathrm{X}, \mathrm{CC} \\
836 \mathrm{~A}-6 \mathrm{X}-1,0-10 \\
836 \mathrm{~A}-6 \mathrm{X}, \mathrm{CC} \\
\text { 836B-1R,CC } \\
\text { 836B-2R,CC }\end{array}$ \\
\hline
\end{tabular}

erates, grits, vitric sands, and clayey siltstone. Unit II, characterized by numerous thick volcaniclastic deposits, was divided into five subunits on the basis of volcanic gravel, vitric sand, and vitric silts. Unit $\mathrm{I}$, which is characterized by a sharp reduction in volcanic ash, formed the topmost unit (Hawkins, Parson, Allan, et al., 1992). Basaltic basement was not encountered.

The lowermost samples of Core 135-838B-13R (Table 5) contain $G$. (T.) truncatulinoides, $G$. (T.) tosaensis, $G$. (G.) decoraperta, $G$. obliquus extremus, and $G$. quadrilobatus fistulosus. Assemblages between Samples 135-838A-15X-CC, 21-24 cm, and -9H-3, 116$121 \mathrm{~cm}$, a part of the sequence with thick volcaniclastic beds, are either barren or of very low diversity, making biostratigraphic studies difficult. Samples 135-838A-8H-CC to $-8 \mathrm{H}-3,10-15 \mathrm{~cm}$, contain the same assemblages as the lower samples. Specimens of $G$. $(G$.) multicamerata, $G$. $(G$.) cultrata limbata or dextrally coiled $G$. $(G$.) cultrata menardii are found from the base of Hole 838B to Sample 135-838A$11 \mathrm{H}-3,17-21 \mathrm{~cm}$. The last appearance of G. quadrilobatus fistulosus

Table 4. Distribution chart, Site 837.

\begin{tabular}{|c|c|c|}
\hline \multicolumn{2}{|r|}{ Biostratigraphy } & \multirow[t]{2}{*}{ Sample } \\
\hline Zone & Subzone & \\
\hline & Bolliella praeadamsi & $\begin{array}{l}837 \mathrm{~A}-1 \mathrm{H}-1,10-14 \\
837 \mathrm{~A}-1 \mathrm{H}-2,138-142 \\
837 \mathrm{~A}-1 \mathrm{H}-4,28-34 \\
\end{array}$ \\
\hline \multirow{3}{*}{$\mathrm{N} 22$} & $\begin{array}{c}\text { Globorotalia (Truncorotalia) } \\
\text { crassaformis hessi }\end{array}$ & $\begin{array}{l}837 \text { A-1H-5,19-24 } \\
837 \text { A-1H,CC } \\
837 \mathrm{~B}-1 \mathrm{R}, \mathrm{CC} \\
837 \mathrm{~A}-2 \mathrm{H}-1,97-102 \\
837 \mathrm{~A}-2 \mathrm{H}-3,60-65 \\
837 \mathrm{~A}-2 \mathrm{H}-4,118-123\end{array}$ \\
\hline & $\begin{array}{c}\text { Globorotalia (Truncorotalia) } \\
\text { crassaformis viola }\end{array}$ & $\begin{array}{l}\text { 837A-2H-6,40-42 } \\
\text { 837A-2H,CC } \\
\text { 837A-3H-1,93-99 } \\
\text { 837A-3H-3,70-75 } \\
\text { 837A-3H-5,54-59 } \\
\text { 837A-3H-6,18-23 } \\
\text { 837A-3H,CC } \\
\text { 837A-4H-1,20-25 } \\
\text { 837A-4H-2,140-144 } \\
\text { 837A-4H-3,60-64 } \\
\text { 837A-4H-6,46-50 } \\
\text { 837A-4H,CC } \\
\text { 837A-5H-1,76-81 } \\
\text { 837A-5H-3,76-81 } \\
\text { 837A-5H-6,75-80 } \\
\text { 837A-6H-5,8-12 } \\
\text { 837A-6H-5,98-104 } \\
\text { 837A-6H-6,97-102 } \\
\text { 837A-6H-7,28-33 } \\
\text { 837A-6H,CC } \\
\text { 837A-7H-1,100-104 } \\
\text { 837A-7H-2,47-52 } \\
\text { 837A-7H-5,79-84 } \\
\text { 837A-7H-6,144-149 } \\
\text { 837A-7H,CC } \\
\text { 837A-8H-1,51-55 } \\
\text { 837A-8H-1,127-131 } \\
\text { 837A-8H-4,23-27 } \\
\text { 837A-8H-5,2-6 } \\
\text { 837A-8H,CCA- }\end{array}$ \\
\hline & $\begin{array}{c}\text { Globigerinoides } \\
\text { quadrilobatus fistulosus }\end{array}$ & $\begin{array}{l}\text { 837A-8H,CCB- } \\
\text { 837B-2R,top } \\
\text { 837B-2R-1,1-4 } \\
\text { 837A-9H-1,121-125 } \\
\text { 837A-9H-2,89-94 } \\
\text { 837A-9H-3,66-70 }\end{array}$ \\
\hline & $\mathrm{N} 21$ & $\begin{array}{l}\text { 837A-9H-4,45-51 } \\
837 \text { A-9H,CC }\end{array}$ \\
\hline
\end{tabular}


Table 5. Distribution chart, Site 838.

\begin{tabular}{|c|c|c|}
\hline \multicolumn{2}{|r|}{ Biostratigraphy } & \multirow{2}{*}{ Sample } \\
\hline Zone & Subzone & \\
\hline $\mathrm{N} 23$ & Bolliella calida calida & $838 \mathrm{~A}-1 \mathrm{H}-1,32-36$ \\
\hline \multirow{4}{*}{$\mathrm{N} 22$} & Bolliella praeadamsi & $\begin{array}{l}838 \mathrm{~A}-1 \mathrm{H}-2,26-30 \\
838 \mathrm{~A}-1 \mathrm{H}-2,120-124 \\
838 \mathrm{~A}-1 \mathrm{H}-3,40-44 \\
838 \mathrm{~A}-1 \mathrm{H}, \mathrm{CC}\end{array}$ \\
\hline & $\begin{array}{c}\text { Globorotalia (Truncorotalia) } \\
\text { crassaformis hessi }\end{array}$ & $\begin{array}{l}838 \mathrm{~A}-2 \mathrm{H}-3,120-125 \\
838 \mathrm{~A}-2 \mathrm{H}-5,40-45 \\
838 \mathrm{~A}-2 \mathrm{H}-5,70-75 \\
838 \mathrm{~A}-2 \mathrm{H}-6,50-55 \\
838 \mathrm{~A}-2 \mathrm{H}, \mathrm{CC} \\
838 \mathrm{~A}-3 \mathrm{H}-2,44-49 \\
838 \mathrm{~A}-3 \mathrm{H}-3,99-105 \\
838 \mathrm{~A}-3 \mathrm{H}-5,43-48 \\
838 \mathrm{~A}-3 \mathrm{H}-6,59-63 \\
838 \mathrm{~A}-3 \mathrm{H}, \mathrm{CC} \\
838 \mathrm{~A}-4 \mathrm{H}-3,129-134 \\
\end{array}$ \\
\hline & $\begin{array}{l}\text { Globorotalia (Truncorotalia) } \\
\text { crassaformis viola }\end{array}$ & $\begin{array}{l}838 \mathrm{~A}-4 \mathrm{H}-4,44-49 \\
838 \mathrm{~A}-4 \mathrm{H}-5,46-51 \\
838 \mathrm{~A}-4 \mathrm{H}-6,27-31 \\
838 \mathrm{~A}-4 \mathrm{H}, \mathrm{CC} \\
838 \mathrm{~A}-5 \mathrm{H}-1,48-53 \\
838 \mathrm{~A}-5 \mathrm{H}-4,146-50 \\
838 \mathrm{~A}-5 \mathrm{H}-5,108-12 \\
838 \mathrm{~A}-5 \mathrm{H}-7,8-12 \\
838 \mathrm{~A}-5 \mathrm{H}, \mathrm{CC} \\
838 \mathrm{~A}-5 \mathrm{H}, \mathrm{CCb} \\
838 \mathrm{~A}-6 \mathrm{H}-1,29-32 \\
838 \mathrm{~A}-6 \mathrm{H}-1,96-101 \\
838 \mathrm{~A}-6 \mathrm{H}-6,98-103 \\
838 \mathrm{~A}-6 \mathrm{H}-6,140-145 \\
838 \mathrm{~A}-6 \mathrm{H}, \mathrm{CC} \\
838 \mathrm{~A}-7 \mathrm{H}-2,59-64 \\
\text { 838A-7H,CC }\end{array}$ \\
\hline & $\begin{array}{c}\text { Globigerinoides } \\
\text { quadrilobatus fistulosus }\end{array}$ & $\begin{array}{l}\text { 838A-8H-3,10-15 } \\
\text { 838A-8H-4,120-125 } \\
\text { 838A-8H-5,50-55 } \\
\text { 838A-8H-6,90-95 } \\
\text { 838A-8H,CC } \\
\text { 838A-9H-1,22-28 } \\
\text { 838A-9H-3,116-21 } \\
\text { 838A-9H-5,33-38 } \\
\text { 838A-9H-5,134-140 } \\
\text { 838A-9H,CC } \\
\text { 838A-11H-3,17-21 } \\
\text { 838A-11H-5,12-17 } \\
\text { 838A-11H,CC } \\
\text { 838A-14X-1,8-9 } \\
\text { 838A-14X-1,18-22 } \\
\text { 838A-14X,CC } \\
\text { 838A-15X-CC,21-24 } \\
\text { 838A-15X,CC } \\
\text { 838A-16X-1,23-27 } \\
\text { 838A-16X-1,52-55 } \\
\text { 838A-17X-CC,6-8 } \\
\text { 838B-2R,CC } \\
\text { 838A-20X-1,129-134 } \\
\text { 838A-20X-1,138-142 } \\
\text { 838A-20X,CC } \\
\text { 838B-9R-CC,16-21 } \\
\text { 838B-11R-1,14-17 } \\
\text { 838B-11R-1,22-25 } \\
\text { 838B-11R,CC } \\
\text { 838B-12R-1,4-7 } \\
\text { 838B-12R-1,11-14 } \\
\text { 838B-12R,CC } \\
\text { 838B-13R-1,17-21 } \\
\text { 838B-13R-1,26-29 } \\
\text { 838B-13R,CC }\end{array}$ \\
\hline
\end{tabular}

is in Sample 135-838A-8H-3, 10-15 cm, and that of $G$. (G.) decoraperta in Sample 135-838A-3H-5, 43-48 cm. G. (T.) crassaformis hessi is first seen in Sample 135-838A-4H-3, 129-134 cm, and the last appearance of $G$. (T.) tosaensis is in Sample 135-838A-3H-5, $43-48 \mathrm{~cm}$, the level at which pink specimens of $G$. ruber are first encountered. Sinistrally dominated populations of Pulleniatina spp. are found at only two levels, Samples $135-838 \mathrm{~A}-8 \mathrm{H}-3,10-15 \mathrm{~cm}$, and $-4 \mathrm{H}-5,46-51 \mathrm{~cm}$; Pulleniatina finalis was not recorded from this site. B. praeadamsi first occurs in Sample 135-838A-1H-CC, followed by B. calida calida in Sample 135-838A-1H-1, 32-36 cm. Rare specimens of G. obliquus extremus and small specimens of Sphaeroidinellopsis paenedehiscens are encountered in a few samples within the interval of Samples 135-838A-8H-CC and -3H-2, $44-49 \mathrm{~cm}$. It is not certain whether these occurrences are caused by reworking, as no other evidence for faunal displacement is present.

\section{Site 839}

The sedimentary sequence is similar to that encountered at Site 838. Unit I is mainly of calcareous ooze with sporadic beds of vitric ash; Unit II is composed mainly of thick bedded vitric sands and silts with interbeds of calcareous ooze; Unit III comprises mainly vitric silts, sands, and gravels (Hawkins, Parson, Allan, et al., 1992). A basaltic sequence underlies Unit III, the top part of which contains interbedded ash beds containing foraminifer assemblages.

$G$. (T.) tosaensis and $G$. (T.) truncatulinoides range from the lowest sample (135-839B-17R-CC; Table 6); the last appearance of G. (T.) tosaensis is in Sample 135-839A-5H-3, 65-69 cm. A questionable specimen of $G$. quadrilobatus fistulosus, with poorly developed fistules, is present in Sample 135-839A-10H-5, 22-28 cm. G. obliquus extremus ranges intermittently from Samples 135-839B-6R-CC to $839 \mathrm{~A}-7 \mathrm{H}-6,118-123 \mathrm{~cm}$, and $G$. (G.) decoraperta from Samples $135-839 \mathrm{~B}-10 \mathrm{R}-\mathrm{CC}$ to $-839 \mathrm{~A}-6 \mathrm{H}-1,52-56 \mathrm{~cm}$. Dextrally coiled specimens of $G$. $(G$.) cultrata menardii are present only in Samples 135839B-6R-CC to $-5 \mathrm{R}-4,134-136 \mathrm{~cm}$. G. (T.) crassaformis hessi first appears in Sample 135-839A-6H-1, 52-56 cm, and ranges to Sample $135-839 \mathrm{~A}-1 \mathrm{H}-2,20-24 \mathrm{~cm}$. B. praeadamsi has its lowest occurrence in Sample 135-839A-4H-5, 90-94 cm, and that of B. calida calida is in Sample 135-839A-1H-1, 17-21 cm. Pulleniatina finalis is confined to Sample $135-839 \mathrm{~A}-4 \mathrm{H}-5,90-94 \mathrm{~cm}$, and sinistrally coiled specimens of Pulleniatina spp. to Sample 135-839A-10H-CC. Pink specimens of Globigerinoides ruber intermittently occur in Samples 135-839A-9H-CC to -1H-CC. Specimens of $G$. (G.) multicamerata and $G$. $(G$.) cultrata limbata have not been recorded.

\section{Site 840}

Site 840 was drilled in the central part of the Tongan Platform. The sequence was divided into three units based on volcaniclastic content (Hawkins, Parsons, Allan, et al., 1992). Unit I is typified by calcareous oozes interbedded with thin vitric silts, sands, and gravels; Unit II is made up of chalks with vitric silts, sands, and gravels; Unit III is composed mainly of volcaniclastic turbidites with interbedded chalks. The turbidites in Unit III tend to become finer grained toward the top of the unit.

Faunal diversity gradually deteriorates down the hole, with the lowest diversity being below Core $135-840 \mathrm{~B}-48 \mathrm{X}$ (Table 7). Below this level a large number of samples proved to be barren of foraminifers. Below Core 135-840B-20X there are fewer barren samples but species diversity is only marginally better than below Core 135-840B$48 \mathrm{X}$. Above Core 135-840B-11X there is a distinct improvement in species diversity; this change appears to be linked with an apparent hiatus based on nannofossil data that occurs between Samples 135840B-11X-CC and -12X-CC (Quinterno, this volume). Support for this hiatus exists, based on the planktonic foraminifer evidence, with the probable absence of much of Zones N19, N19-20, and some of N21 supporting such a conclusion. The absence or rarity of some key 
Table 6. Distribution chart, Site 839.

\begin{tabular}{|c|c|c|}
\hline \multicolumn{2}{|r|}{ Biostratigraphy } & \multirow{2}{*}{ Sample } \\
\hline Zone & Subzone & \\
\hline $\mathrm{N} 23$ & Bolliella calida calida & $839 \mathrm{~A}-1 \mathrm{H}-1,17-21$ \\
\hline \multirow{4}{*}{$\mathrm{N} 22$} & Bolliella praeadamsi & $\begin{array}{l}839 \mathrm{~A}-1 \mathrm{H}-1,102-106 \\
839 \mathrm{~A}-1 \mathrm{H}-2,20-24 \\
839 \mathrm{~A}-1 \mathrm{H}-3,43-47 \\
839 \mathrm{~A}-1 \mathrm{H}, \mathrm{CC} \\
839 \mathrm{~A}-2 \mathrm{H}-2,124-128 \\
839 \mathrm{~A}-2 \mathrm{H}-4,15-19 \\
839 \mathrm{~A}-2 \mathrm{H}-5,95-99\end{array}$ \\
\hline & $\begin{array}{c}\text { Globorotalia (Truncorotalia) } \\
\text { crassaformis hessi }\end{array}$ & $\begin{array}{l}\text { 839A-2H-6,18-22 } \\
\text { 839A-2H,CC } \\
\text { 839A-3H-1,118-129 } \\
\text { 839A-3H-2,20-24 } \\
\text { 839A-3H-3,20-24 } \\
\text { 839A-3H-3,48-52 } \\
\text { 839A-3H,CC } \\
\text { 839A-4H-5,63-67 } \\
\text { 839A-4H-5,90-94 } \\
\text { 839A-4H-5,115-119 } \\
\text { 839A-4H-6,90-94 } \\
\text { 839A-4H,CC } \\
\text { 839A-5H-2,108-112 } \\
\text { 839A-5H-3,65-69 } \\
\text { 839A-5H-4,134-136 } \\
\text { 839A-5H-5,130-134 } \\
\text { 839A-5H,CC } \\
\text { 839A-6H-1,16-20 } \\
\text { 839A-6H-1,52-56 }\end{array}$ \\
\hline & $\begin{array}{l}\text { Globorotalia (Truncorotalia) } \\
\text { crassaformis viola } \\
\\
? \\
\end{array}$ & $\begin{array}{l}839 \text { A-6H-2,44-48 } \\
839 \text { A-6H-2,60-64 } \\
839 \text { A-6H,CC } \\
839 \text { A-7H-1,44-49 } \\
839 \text { A-7H-2,105-109 } \\
\text { 839A-7H-4,99-103 } \\
839 \text { A-7H-6,118-123 } \\
\text { 839A-7H,CC } \\
\text { 839A-8H-3,32-36 } \\
\text { 839A-8H-5,122-126 } \\
839 \text { A-8H-6,42-46 } \\
\text { 839A-8H-6,145-149 } \\
\text { 839A-8H,CC } \\
\text { 839A-9H,CC } \\
\text { 839A-10H-1,90-95 } \\
\text { 839A-10H-4,71-76 }\end{array}$ \\
\hline & $\begin{array}{c}\text { Globigerinoides } \\
\text { quadrilobatus fistulosus }\end{array}$ & $\begin{array}{l}839 \mathrm{~A}-10 \mathrm{H}-5,22-28 \\
839 \mathrm{~A}-10 \mathrm{H}-5,62-67 \\
839 \mathrm{~A}-10 \mathrm{H}, \mathrm{CC} \\
\text { 839A-11H-2,66-71 } \\
\text { 839A-11H-3,80-85 } \\
\text { 839A-11H-4,132-137 } \\
\text { 839A-11H-6,0-5 } \\
\text { 839A-11H,CC } \\
\text { 839A-12X,CC } \\
\text { 839B-3R,CC } \\
\text { 839B-4R,CC } \\
\text { 839A-15X,CC } \\
\text { 839A-17X,CC } \\
\text { 839A-18X,CC } \\
\text { 839A-20X,CC } \\
\text { 839B-5R,CC } \\
\text { 839B-6R,CC } \\
\text { 839A-21X,CC } \\
\text { 839B-7R,CC } \\
\text { 839B-8R,CC } \\
\text { 839A-22X,CC } \\
\text { 839B-9R,CC } \\
\text { 839B-10R,CC } \\
\text { 839A-23X,CC } \\
\text { 839B-11R,CC } \\
\text { 839B-17R,CC }\end{array}$ \\
\hline
\end{tabular}

taxa reflects the poor faunal assemblages and has made the location of biostratigraphic boundaries difficult.

The lowest samples from Core 135-840B-63X contain $G$. $(G$.) tumida plesiotumida, $G$. (G.) merotumida, and Candeina nitida nitida. $G$. (G.) lenguaensis is present in Sample 135-840B-61X-4, 16-21 cm, and $G$. (G.) paralenguaensis in Sample 135-840B-62X-3, 80-85 cm. Pulleniatina primalis first appears in Sample 135-840B-26X-CC, but the FAs of Sphaeroidinellopsis paenedehiscens in Sample 135-840B$60 \mathrm{X}-5,51-56 \mathrm{~cm}$, of $G$. (G.) multicamerata in Sample 135-840B-39X$1,89-95 \mathrm{~cm}$, of Globigerinoides conglobatus in Sample 135-840B40X-CC, and of G. (O.) margaritae in Sample 135-840B-31X-CC. In addition, the populations of $P$. primalis are dominated by sinistrally coiled specimens.

The highest $G$. (G.) paralenguaensis is at Sample 135-840C-8H$5,117-122 \mathrm{~cm}$, and that of $G$. (G.) lenguaensis at Sample 135-840B$28 \mathrm{X}-1,104-106 \mathrm{~cm}$. G. (G.) tumida tumida ranges from Sample 135$840 \mathrm{~B}-20 \mathrm{X}-\mathrm{CC}$, and the highest occurrence of $G$. $(G$.) merotumida is in Sample 135-840B-29X-1, 50-52 cm, and that of $G$. (G.) tumida plesiotumida in Sample 135-840B-12X-4, 89-93 cm. Sphaeroidinella dehiscens ranges from Sample 135-840B-11X-CC, followed by G. (T.) crassaformis crassaformis in Sample 135-840B-10X-CC. $G$. (G.) nepenthes ranges no higher than Sample 135-840B-12X-4, $89-93 \mathrm{~cm} ; G$. (O.) margaritae ranges to Sample 135-840B-10X-CC. $G$. (T.) tosaensis first appears in Sample 135-840C-4H-CC with $G$. quadrilobatus fistulosus; this joint appearance suggests that this is not the true evolutionary first appearance level of $G$. (T.) tosaensis. The last appearance (LA) of D. altispira altispira is in Sample 135$840 \mathrm{C}-4 \mathrm{H}-2,78-82 \mathrm{~cm}$. G. quadrilobatus fistulosus disappears above Sample 135-840C-3H-CC, before the FA of $G$. (T.) truncatulinoides in Sample 135-840C-2H-CC. The LAs of G. (T.) tosaensis, G. (G.) cultrata limbata, and G. (G.) multicamerata are in Sample 135-840B$2 \mathrm{X}-\mathrm{CC}$, but $G$. (T.) crassaformis hessi is confined to a few samples above Sample 135-840A-1H-3, 2-6 cm. Rare specimens of $B$. praeadamsi are present above Sample 135-840A-1H-3, 2-6 cm; $P$. finalis is confined to this sample.

Pink specimens of G. ruber range from Sample 135-840B-1X-CC. The LA of G. obliquus extremus is in Sample 135-840B-4X-CC, and that of G. obliquus obliquus is in Sample 135-840B-3X-CC. Populations of Pulleniatina spp. dominated by sinistrally coiled specimens are present from Sample 135-840B-26X-CC to Sample 135-840B$10 X-C C$. Populations of $G$. $(G$.) cultrata menardii vary from those dominated by dextrally coiled individuals to those dominated by sinistral coiling; Table 8 shows the variation in coiling direction throughout the section at Site 840 . As can be seen, coiling has changed on nine occasions; except for the intervals between Sample 135-840B$28 \mathrm{X}-1,104-106 \mathrm{~cm}$, and $-29 \mathrm{X}-1,50-52 \mathrm{~cm}$, and between Samples 135-840B-43X-3, 67-71 cm, and -50X-CC, where coiling is random, the coiling changes are rapid and constant. Stainforth et al. (1975) noted that changes in coiling direction may have been controlled by sharp changes in water temperature.

\section{Site 841}

Site 841 was drilled in water depths close to $4810 \mathrm{~m}$, that is, well below the CCD. The middle Miocene-Quaternary section of Site 841 is divided into three units (Hawkins, Parsons, Allan, et al., 1992). Unit I is made up of structureless clays with very thin interbedded vitric silts, sands, and ash beds. Unit II differs from Unit I by having more beds of vitric silts and sands that increase in frequency downhole. Unit III is dominated by volcanic conglomerate interbedded with vitric siltstone and sandstone; reworked late Eocene larger foraminifers are present in the lower part. The base of the unit is a fault breccia, marking the boundary with Unit IV. The sediments of Units I to III are at best weakly calcareous; they are either barren of calcareous microfossils or contain very poor assemblages. Unit IV is made up of calcareous volcanic siltstones, sandstones, and conglomerates; the sequence becomes finer grained upward. The discussion here is based 
Table 7. Distribution chart, Site 840.

\begin{tabular}{|c|c|c|}
\hline \multicolumn{2}{|r|}{ Biostratigraphy } & \multirow[t]{2}{*}{ Sample } \\
\hline Zone & Subzone & \\
\hline & Bolliella praeadamsi & $\begin{array}{l}840 \mathrm{~A}-1 \mathrm{H}-1,120-124 \\
840 \mathrm{~A}-1 \mathrm{H}-2,113-117 \\
840 \mathrm{~A}-1 \mathrm{H}-3,2-6\end{array}$ \\
\hline & $\begin{array}{c}\text { Globorotalia (Truncorotalia) } \\
\text { crassaformis hessi }\end{array}$ & $\begin{array}{l}840 \mathrm{~A}-1 \mathrm{H}, \mathrm{CC} \\
840 \mathrm{~B}-1 \mathrm{X}-1,47-49\end{array}$ \\
\hline & $\begin{array}{c}\text { Globorotalia (Truncorotalia) } \\
\text { crassaformis viola }\end{array}$ & $\begin{array}{l}840 \mathrm{~B}-1 \mathrm{X}-1,88-90 \\
840 \mathrm{~B}-1 \mathrm{X}-1,124-126 \\
840 \mathrm{~B}-1 \mathrm{X}-1,130-132 \\
840 \mathrm{~B}-1 \mathrm{X}, \mathrm{CC} \\
840 \mathrm{~B}-2 \mathrm{X}, \mathrm{CC} \\
840 \mathrm{~B}-3 \mathrm{X}, \mathrm{CC}\end{array}$ \\
\hline & $\begin{array}{l}\text { Globigerinoides } \\
\text { quadrilobatus fistulosus }\end{array}$ & $\begin{array}{l}840 \mathrm{~B}-4 \mathrm{X}, \mathrm{CC} \\
840 \mathrm{C}-1 \mathrm{H}-3,30-35 \\
840 \mathrm{C}-1 \mathrm{H}-3,46-49 \\
840 \mathrm{C}-1 \mathrm{H}, \mathrm{CC} \\
840 \mathrm{C}-2 \mathrm{H}-1,30-35 \\
840 \mathrm{C}-2 \mathrm{H}, \mathrm{CC} \\
\end{array}$ \\
\hline & N21 & $\begin{array}{l}840 \mathrm{C}-3 \mathrm{H}-2,92-96 \\
840 \mathrm{C}-3 \mathrm{H}-3,138-143 \\
840 \mathrm{C}-3 \mathrm{H}, \mathrm{CC} \\
840 \mathrm{C}-4 \mathrm{H}-2,78-82 \\
840 \mathrm{C}-4 \mathrm{H}, \mathrm{CC} \\
\end{array}$ \\
\hline & N19-20 & \begin{tabular}{|l|}
$840 \mathrm{~B}-9 \mathrm{X}, \mathrm{CC}$ \\
$840 \mathrm{~B}-10 \mathrm{X}, \mathrm{CC}$ \\
\end{tabular} \\
\hline & N19 & $\begin{array}{l}440 \mathrm{~B}-11 \mathrm{X}-2,22-27 \\
840 \mathrm{~B}-11 \mathrm{X}, \mathrm{CC} \\
\end{array}$ \\
\hline & N18 & $\begin{array}{l}840 \mathrm{~B}-12 \mathrm{X}-4,89-93 \\
840 \mathrm{~B}-12 \mathrm{X}-6,8-15 \\
840 \mathrm{~B}-12 \mathrm{X}, \mathrm{CC} \\
840 \mathrm{~B}-13 \mathrm{X}-1,120-124 \\
840 \mathrm{~B}-13 \mathrm{X}-3,127-130 \\
840 \mathrm{~B}-13 \mathrm{X}, \mathrm{CC} \\
840 \mathrm{C}-5 \mathrm{H}-2,134-38 \\
840 \mathrm{C}-5 \mathrm{H}, \mathrm{CC} \\
840 \mathrm{C}-6 \mathrm{H}-4,34-39 \\
840 \mathrm{C}-6 \mathrm{H}, \mathrm{CC} \\
840 \mathrm{~B}-15 \mathrm{X}, \mathrm{CC} \\
840 \mathrm{C}-7 \mathrm{H}-4,138-143 \\
840 \mathrm{C}-7 \mathrm{H}, \mathrm{CC} \\
840 \mathrm{C}-8 \mathrm{H}-5,117-122 \\
840 \mathrm{C}-8 \mathrm{H}, \mathrm{CC} \\
840 \mathrm{~B}-17 \mathrm{X}, \mathrm{CC} \\
840 \mathrm{C}-9 \mathrm{H}-1,52-54 \\
840 \mathrm{C}-9 \mathrm{H}-1,102-104 \\
840 \mathrm{C}-9 \mathrm{H}, \mathrm{CC} \\
840 \mathrm{~B}-18 \mathrm{X}, \mathrm{CC} \\
840 \mathrm{C}-10 \mathrm{H}-1,57-59 \\
840 \mathrm{C}-10 \mathrm{H}-3,37-41 \\
840 \mathrm{C}-10 \mathrm{H}, \mathrm{CC} \\
840 \mathrm{~B}-19 \mathrm{X}, \mathrm{CC} \\
840 \mathrm{C}-11 \mathrm{H}-1,12-14 \\
840 \mathrm{C}-11 \mathrm{H}, \mathrm{CC} \\
840 \mathrm{~B}-20 \mathrm{X}, \mathrm{CC} \\
\end{array}$ \\
\hline & N17B & $\begin{array}{l}840 \mathrm{C}-12 \mathrm{H}-1,13-17 \\
840 \mathrm{C}-12 \mathrm{H}, \mathrm{CC} \\
840 \mathrm{~B}-22 \mathrm{X}, \mathrm{CC} \\
840 \mathrm{~B}-23 \mathrm{X}, \mathrm{CC} \\
840 \mathrm{~B}-24 \mathrm{X}-1,44-46 \\
840 \mathrm{~B}-24 \mathrm{X}-1,116-112 \\
840 \mathrm{~B}-24 \mathrm{X}, \mathrm{CC} \\
840 \mathrm{~B}-26 \mathrm{X}-1,36-38 \\
840 \mathrm{~B}-26 \mathrm{X}, \mathrm{CC} \\
840 \mathrm{C}-13 \mathrm{H}, \mathrm{CC} \\
840 \mathrm{~B}-28 \mathrm{X}-1,104-106 \\
840 \mathrm{~B}-28 \mathrm{X}-2,85-87 \\
840 \mathrm{~B}-28 \mathrm{X}, \mathrm{CC} \\
840 \mathrm{~B}-29 \mathrm{X}-1,15-17 \\
840 \mathrm{~B}-29 \mathrm{X}-1,50-52 \\
840 \mathrm{~B}-29 \mathrm{X}, \mathrm{CC} \\
840 \mathrm{~B}-30 \mathrm{X}-1,18-20 \\
840 \mathrm{~B}-30 \mathrm{X}, \mathrm{CC} \\
840 \mathrm{~B}-31 \mathrm{X}-1,26-27 \\
840 \mathrm{~B}-31 \mathrm{X}, \mathrm{CC} \\
840 \mathrm{~B}-32 \mathrm{X}-1,13-14 \\
\end{array}$ \\
\hline
\end{tabular}

Table 7 (continued).

\begin{tabular}{|c|c|c|}
\hline \multicolumn{2}{|c|}{ Biostratigraphy } & \multirow[t]{2}{*}{ Sample } \\
\hline Zone & Subzone & \\
\hline & & $\begin{array}{l}\text { 840B-32X,CC } \\
840 \mathrm{~B}-33 \mathrm{X}-1,104-106 \\
840 \mathrm{~B}-33 \mathrm{X}, \mathrm{CC} \\
840 \mathrm{~B}-34 \mathrm{X}, \mathrm{CC} \\
840 \mathrm{~B}-35 \mathrm{X}-2,38-40 \\
840 \mathrm{~B}-35 \mathrm{X}-3,48-50 \\
840 \mathrm{~B}-35 \mathrm{X}, \mathrm{CC} \\
840 \mathrm{~B}-36 \mathrm{X}-1,80-82 \\
840 \mathrm{~B}-36 \mathrm{X}, \mathrm{CC} \\
840 \mathrm{~B}-37 \mathrm{X}-2,2-7 \\
840 \mathrm{~B}-37 \mathrm{X}, \mathrm{CC} \\
\text { 840B-38X,CC } \\
\text { 840B-39X-1,89-95 } \\
\end{array}$ \\
\hline & N17A & 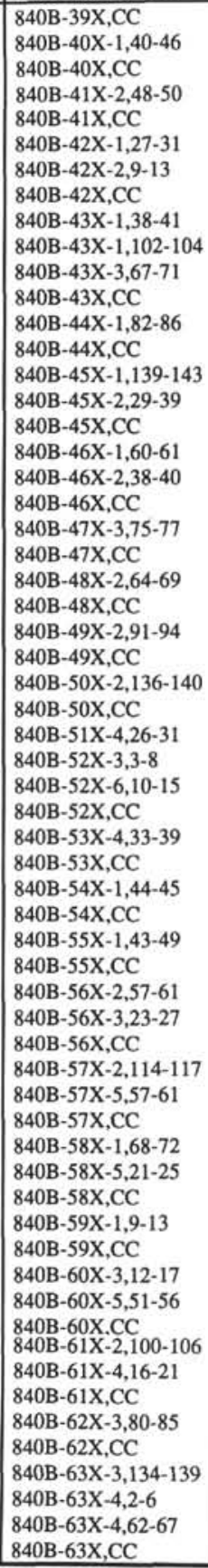 \\
\hline
\end{tabular}


Table 8. Dominant coiling direction for populations of Globorotalia (G.) cultrata group over different intervals at Site $\mathbf{8 4 0}$.

\begin{tabular}{clc}
\hline Depth (mbsf) & \multicolumn{1}{c}{ Sample interval } & Coiling direction \\
\hline $0-9.5$ & Top to 840B-1X-CC & Sinistral \\
$18.9-126.9$ & $840 \mathrm{~B}-2 \mathrm{X}-\mathrm{CC}$ to $840 \mathrm{C}-2 \mathrm{H}, 134-138 \mathrm{~cm}$ & Dextral \\
$133.5-159.7$ & $840 \mathrm{C}-5 \mathrm{H}-\mathrm{CC}$ to $840 \mathrm{C} 8 \mathrm{H}-5,110-122 \mathrm{~cm}$ & Sinistral \\
$162.0-240.8$ & $840 \mathrm{C}-8 \mathrm{H}-\mathrm{CC}$ to $840 \mathrm{~B}-26 \mathrm{X}-1,36-38 \mathrm{~cm}$ & Dextral \\
$260.7-270.0$ & $840 \mathrm{~B}-28 \mathrm{X}-1,104-106 \mathrm{~cm}$, to $840 \mathrm{~B}-29 \mathrm{X}-1,50-52 \mathrm{~cm}$ & Sinistral \\
$279.2-327.5$ & $840 \mathrm{~B}-30 \mathrm{X}-1,18-20 \mathrm{~cm}$, to $840 \mathrm{~B}-34 \mathrm{X}-\mathrm{CC}$ & Dextral \\
$329.3-376.2$ & $840 \mathrm{~B}-35 \mathrm{X}-2,38-40 \mathrm{~cm}$, to $840 \mathrm{~B}-40 \mathrm{X}-\mathrm{CC}$ & Dextral \\
$378.2-471.7$ & $840 \mathrm{~B}-41 \mathrm{X}-2,48-50 \mathrm{~cm}$, to $840 \mathrm{~B}-50 \mathrm{X}-\mathrm{CC}$ & Variable (mainly sinistral) \\
$476.4-597.3$ & $840 \mathrm{~B}-51 \mathrm{X}-4,26-31 \mathrm{~cm}$, to bottom & Dextral \\
\hline
\end{tabular}

Table 9. Distribution chart, Site 841.

\begin{tabular}{|c|c|}
\hline$\frac{\text { Biostratigraphy }}{\text { Zone }}$ & Sample \\
\hline N16 to N19-20 & $\begin{array}{l}841 \mathrm{~B}-2 \mathrm{R}, \mathrm{CC} \\
841 \mathrm{~B}-5 \mathrm{R}, \mathrm{CC} \\
841 \mathrm{~B}-6 \mathrm{R}, \mathrm{CC} \\
841 \mathrm{~B}-7 \mathrm{R}, \mathrm{CC} \\
841 \mathrm{~B}-9 \mathrm{R}, \mathrm{CC} \\
841 \mathrm{~B}-11 \mathrm{R}, \mathrm{CC} \\
\text { 841B-12R,CC } \\
\text { 841B-13R,CC } \\
\text { 841B-15R,CC } \\
\text { 841B-16R,CC }\end{array}$ \\
\hline ?N16 to N17A? & $\begin{array}{l}\text { 841B-17R,CC } \\
841 \mathrm{~B}-19 \mathrm{R}, \mathrm{CC} \\
841 \mathrm{~B}-21 \mathrm{R}, \mathrm{CC} \\
841 \mathrm{~B}-22 \mathrm{R}, \mathrm{CC} \\
841 \mathrm{~B}-23 \mathrm{R}, \mathrm{CC} \\
841 \mathrm{~B}-28 \mathrm{R}, \mathrm{CC} \\
841 \mathrm{~B}-29 \mathrm{R}, \mathrm{CC} \\
\end{array}$ \\
\hline N9 & $\begin{array}{l}841 \mathrm{~B}-32 \mathrm{R}-2,19-23 \\
841 \mathrm{~B}-32 \mathrm{R}, \mathrm{CC} \\
841 \mathrm{~B}-33 \mathrm{R}, \mathrm{CC} \\
841 \mathrm{~B}-34 \mathrm{R}, \mathrm{CC} \\
841 \mathrm{~B}-35 \mathrm{R}, \mathrm{CC} \\
841 \mathrm{~B}-36 \mathrm{R}, \mathrm{CC}\end{array}$ \\
\hline N8 & $\begin{array}{l}841 \mathrm{~B}-37 \mathrm{R}, \mathrm{CC} \\
841 \mathrm{~B}-38 \mathrm{R}, \mathrm{CC} \\
841 \mathrm{~B}-39 \mathrm{R}, \mathrm{CC}\end{array}$ \\
\hline P18 & $\begin{array}{l}841 \mathrm{~B}-40 \mathrm{R}, \mathrm{CC} \\
841 \mathrm{~B}-41 \mathrm{R}, \mathrm{CC}\end{array}$ \\
\hline
\end{tabular}

only on the study of a few core-catcher samples and two core samples from the base of Unit III.

Planktonic foraminifers are very rare and sporadic throughout Units I-III (Table 9). G. (G.) nepenthes is present in Samples 135841B-29R-CC and -20R-1, 104-107 cm. G. kennetti is present in Sample 135-841B-19R-CC, and G. obliquus extremus with $G$. $(G$.) nepenthes in Sample 135-841B-2R-CC; the latter is also present in Sample 135-841A-20X-CC, and is present in most assemblages above Sample 135-841B-29R-CC. Samples 135-841A-17X-CC-841-19X-CC contain N. acostaensis. $G$. $(G$.) lenguaensis and $G$. $(G$.) tumida plesiotumida are present in Sample 135-841A-10X-CC, and the latter subspecies with $G$. (G.) merotumida in Sample 135-841A-8X-CC. Above these levels the samples were barren.

\section{BIOSTRATIGRAPHIC RESULTS}

The biostratigraphic scheme followed here for the Quaternary is that of Bolli and Premoli Silva (1973), as modified and extended by Chaproniere (1991). For the Neogene, that of Blow (1969), as modified by Kennett and Srinivasan (1983), has been employed. The time scale of Berggren et al. (1985) has been adopted for this paper. Only the basal subzone of Zone N23 (the Bolliella calida calida Subzone) was recognized in this study. The sediments containing assemblages of the younger zones were probably removed during drilling operations.

Figure 2 summarizes the biostratigraphic scheme and location of the main bioevents used in this paper. Figure 3 summarizes the correlations between the various Lau Basin sites, and Figure 4, the correlations between the two Tongan Platform sites.

\section{Lau Basin Sites}

\section{Zone NI7B}

Site 834 was the only Lau Basin site to penetrate this zone. The presence of $G$. (G.) tumida plesiotumida below the FA of $G$. $(G$.) tumida tumida, together with the presence of Pulleniatina primalis indicates Zone N17B. Only sediments interbedded within the basalts are referred to this zone. The presence of $G$. (G.) multicamerata and $G$. (Obandyella) margaritae indicates that the sediments can be no older than Zone N17B.

\section{Zone N18}

Zone N18 is characterized by the interval between the FA of $G$. (G.) tumida tumida and the FA of Sphaeroidinella dehiscens (Blow, 1969). This association occurs within the interbedded sediments in the upper part of the basaltic sequence and those immediately overlying that sequence at Site 834.

Populations of $P$. primalis dominated by dextrally coiled specimens occur at the base of the Zone N18 and sinistrally coiled ones at the top of the zone at Site 834 .

\section{Zone N19}

The FA of S. dehiscens marks the base of Zone N19 (Blow, 1969), and this event occurs within the lower part of the sedimentary section overlying the basalt sequence in Holes 834A and 834B. The zonal marker is present in the lowest sample from Hole $835 \mathrm{~A}$ directly overlying the basaltic sequence. Because $G$. (T.) crassaformis was not present below the FA of $G$. (T.) tosaensis, and no evidence is present for a hiatus in this part of the sequence, the sediments below the FA of $G$. (T.) tosaensis have been referred to the N19 to N19-20 zonal interval.

\section{Zone N19-20}

Zone N19-20 is based on the FA of $G$. (T.) crassaformis crassaformis (Kennett and Srinivasan, 1983). At Site 834 this event is placed within Core 135-834A-11X, between Samples 135-834A-11X-1, 63$67 \mathrm{~cm}$, and $-11 X-2,100-104 \mathrm{~cm}$. G. (O.) margaritae disappears within the uppermost part of this zone at Site 834. At Site 835 it is not possible to recognize this zone because of the poor preservation of the faunas; the lowest occurrence of $G$. (T.) crassaformis crassaformis is at the same level as that of $G$. (T.) tosaensis. 


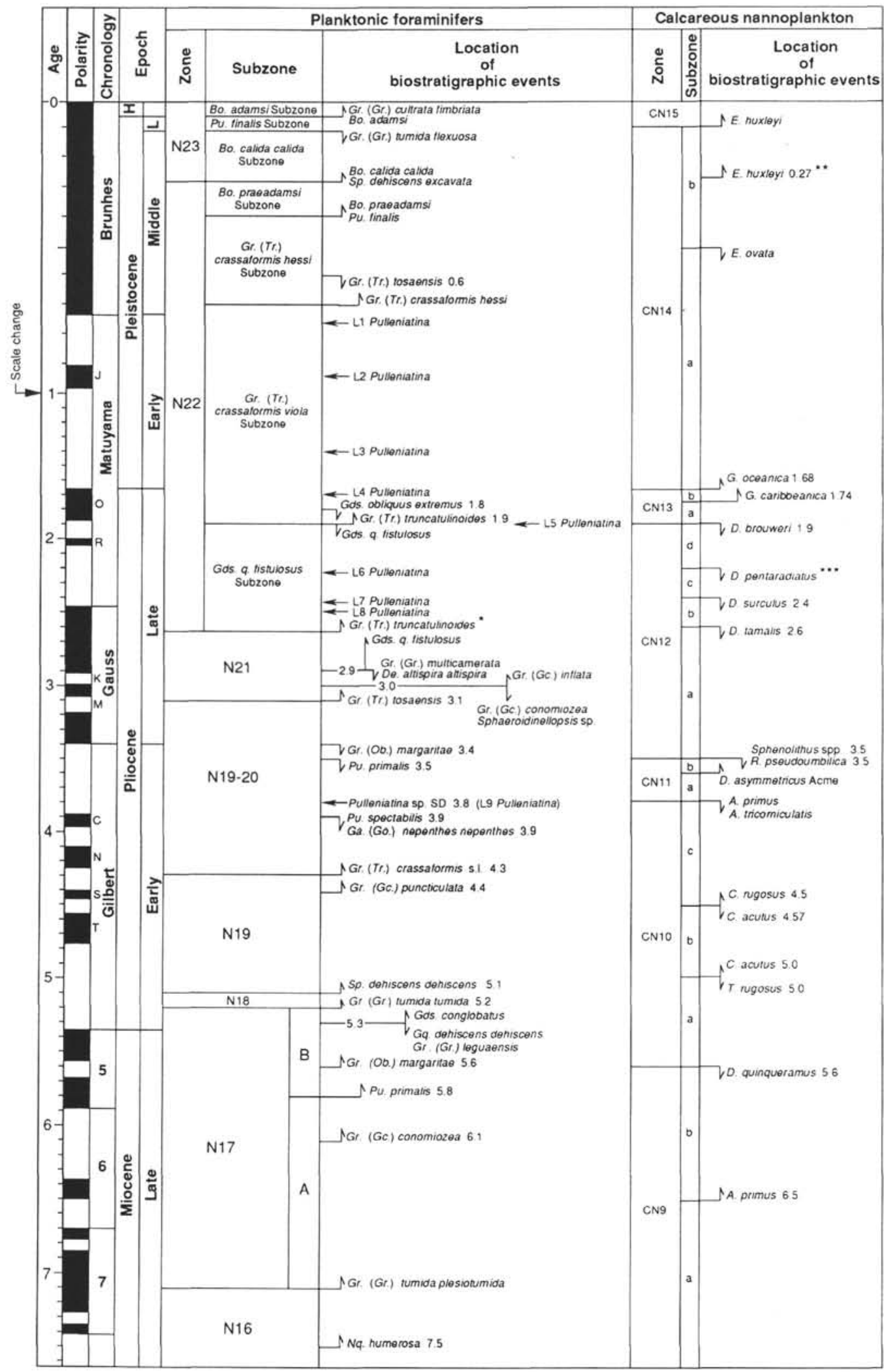

Figure 2. Biostratigraphic zonal scheme and events used in this study. Time scale after Berggren et al. (1985); zonal scheme after Blow (1969), Kennett and Srinivasan (1983), and Chaproniere (1991). Abbreviations for planktonic foraminifers: Bo. $=$ Bolliella, De $=$ Dentoglobigerina, Ga. = Globigerina, Go. $=$ Globoturborotalita, Gds. = Globigerinoides, $G q .=$ Globoquadrina, $G c .=$ Globoconella, $G r .=$ Globorotalia, $N q .=$ Neogloboquadrina, $O b .=$ Obandyella, $P$ P. $=$ Pulleniatina, $S p .=$ Sphaeroidinella, $T r .=$ Truncorotalia . Abbreviations for calcareous nannoplankton: $A .=$ Amaurolithus, $C$. = Ceratolithus, $D .=$ Discoaster $E .=$ Emiliania, $G .=$ Gephyrocapsa, $R .=$ Reticulofenestra, $S .=$ Sphenolithus, $T$. $=$ Triquetrorhabdulus. Asterisk $(*)=$ location of bioevent as used in this study (see Chaproniere et al., this volume). 


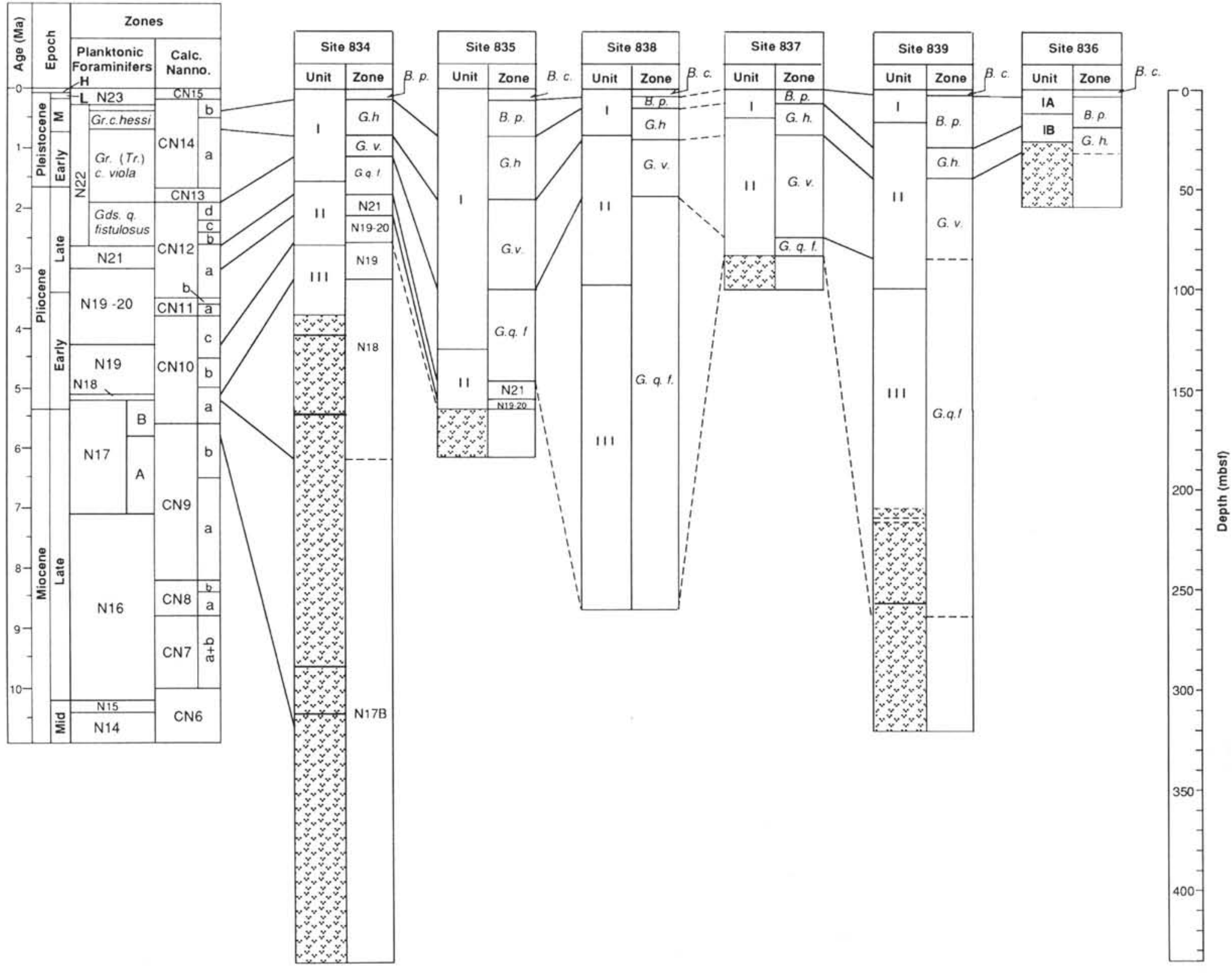






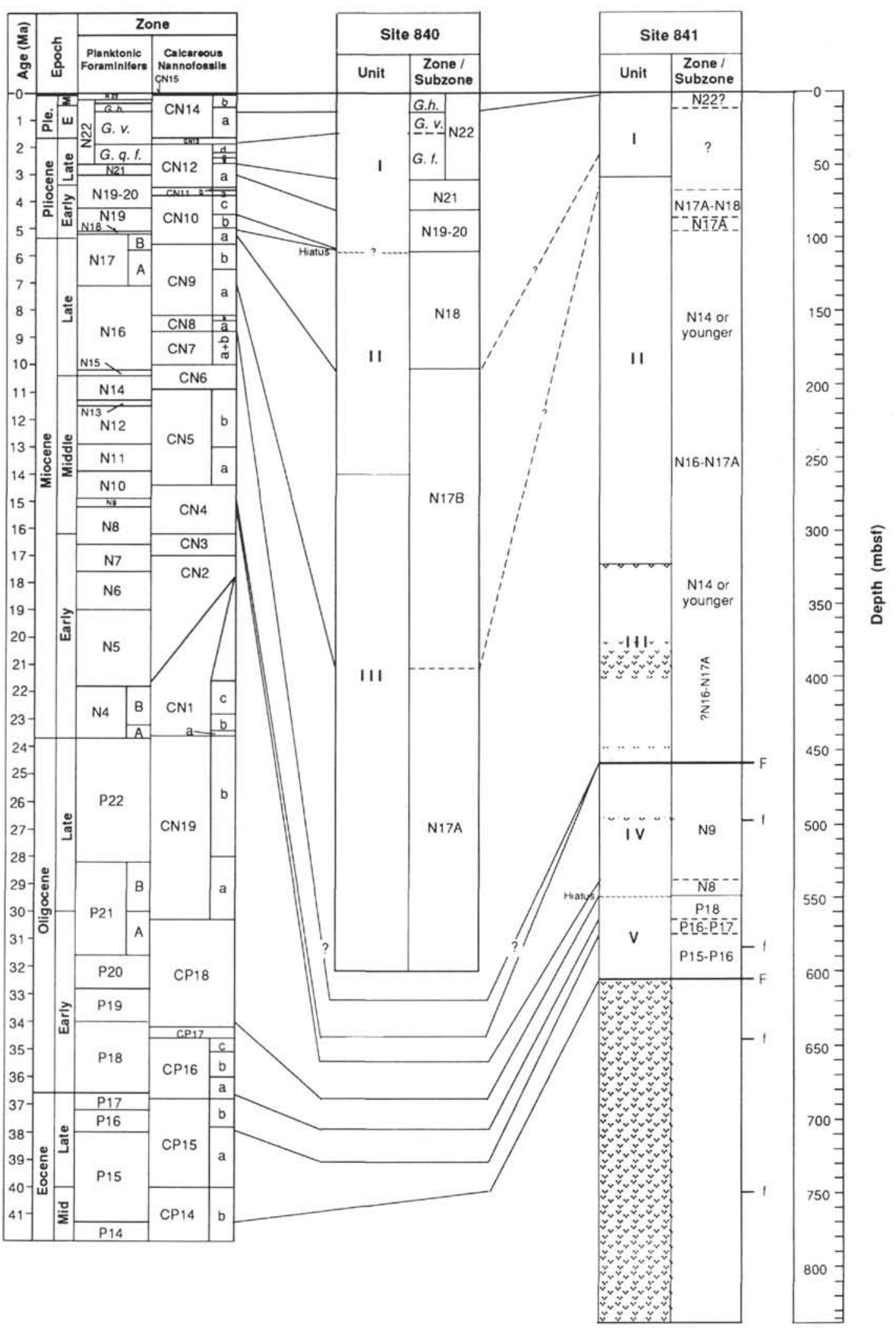

Figure 4. Biostratigraphic summary and correlation among the Tongan Platform sites (Sites 840 and 841 ). 


\section{Zone N21}

The FA of $G$. (T.) tosaensis marks the base of Zone N21. This event is placed between Samples 135-834A-7H-4, 99-104 cm, and -7H-6, $40-45 \mathrm{~cm}$, at Site 834. At this site the FA of $G$. (T.) tosaensis occurs above the FA of G. quadrilobatus fistulosus. According to Kennett and Srinivasan (1983) and Berggren et al. (1985), the FA of G. quadrilobatus fistulosus takes place well after that of $G$. (T.) tosaensis, implying that the latter event may be environmentally controlled. Similarly, at Site 835 the FA of G. quadrilobatus fistulosus occurs immediately below the FA of $G$. (T.) truncatulinoides. Thus, it would seem that both events may be unreliable in this region.

\section{Zone N22}

The FA of $G$. (T.) truncatulinoides marks the base of Zone N22 (Blow, 1969). This zone has been subdivided into three subzones by Chaproniere (1991), and these subzones have been recognized within the Lau Basin.

\section{Globigerinoides quadrilobatus fistulosus Subzone}

This subzone is defined by that part of the range of G. quadrilobatus fistulosus that overlaps with that of $G$. (T.) truncatulinoides (Chaproniere, 1991). This subzone was recognized at Sites 834, 835, 837 , and 838 ; it was questionably recognized at Site 839 .

At Site 835 the position of the top of this subzone has not been placed with confidence because of the reworking of faunas from Zone $\mathrm{N} 21$ (based on the presence of Dentoglobigerina altispira altispira, G. quadrilobatus fistulosus, $G$. $(G$.) multicamerata, and $G$. (T.) tosaensis). The location of the upper boundary at this site is based on the reappearance (because of reworking) of D. altispira altispira, and G. (G.) multicamerata in Sample 135-835A-9H-7, 49-54 cm.

Globorotalia (Truncorotalia) crassaformis viola Subzone

The base of this subzone is defined by the LA of G. quadrilobatus fistulosus. G. (T.) tosaensis ranges through this subzone. This subzone was recognized at all sites except Site 836 . As noted above, the position of the base of this subzone at Site 835 is not placed with confidence; it is placed at the lowest level where reworked specimens from Zone N21 clearly occur. This reworking has continued to the top of the hole and is almost certainly a result of erosion and slumping from the sides of a small, isolated basin.

\section{Globorotalia (Truncorotalia) crassaformis hessi Subzone}

The FA of $G$. (T.) crassaformis hessi marks the base of this subzone (Chaproniere, 1991). The LA of $G$. (T.) tosaensis occurs in the lowermost parts of this subzone. This subzone was recognized at all sites from the Lau Basin.

At Site 836, sediments containing this subzonal assemblage immediately overlie basaltic basement. It was within this subzone at Site 834 that reworking of material from Zone N21 was first observed. This may have been related to sea-level fluctuations.

\section{Bolliella praeadamsi Subzone}

This subzone is defined by the FA of $B$. praeadamsi (Chaproniere, 1991). Though this species is fairly rare, it was recognized at all sites. At Site 834 reworking of faunas from Zone N21 faunas, initiated during the preceding subzone, continued. The FA of Pulleniatina finalis seems to occur at the same time as that of B. praeadamsi (Chaproniere, 1991). This species is rare in the sections studied; at Site 834 this event occurs above the FA of B. praeadamsi, at Site 835 it occurs at the same level, at Site 836 immediately below, and at Site 839 it is present in only one sample, that in which $B$. praeadamsi first appears; it is absent from Sites 837 and 838 . The rarity of $P$. finalis in these sections precludes its biostratigraphic usefulness.

\section{Zone N23}

Zone N23 is defined by the FA of B. calida calida (Blow, 1969). This subspecies is distinguished by the distinct radial elongation of the final chambers, as well as having 4.5 or more chambers in the final whorl (Blow, 1969; Chaproniere, 1991).

\section{Bolliella calida calida Subzone}

This subzone, which is defined by the overlap of $B$. calida calida and G. (G.) tumida flexuosa (Chaproniere, 1991), is the lowest of three subdivisions of Zone N23. It was recognized only at Sites 835, 836,838 , and 839 ; sediments containing this subzone were probably removed by drilling operations at Sites 834 and 837 .

\section{Younger Subzones}

Chaproniere (1991) recognized two subzones overlying the $B$. calida calida, the $P$. finalis, and $B$. adamsi Subzones. These were not recorded at any sites, and therefore we conclude that they were probably removed by coring operations.

\section{Tonga Ridge Sites}

Site 840 penetrated through the Quaternary to the late Miocene; the assemblages are not as diverse or well preserved as those from the Lau Basin sites, a feature that may be the result of diagenetic factors caused by the alteration of volcanic products. At Site 841 the Quaternary and Pliocene part of the sequence is barren and the upper Miocene, which is almost barren of calcareous microfossils, is faulted against a middle Miocene section not found at the other sites.

\section{Zone N8}

The presence of Praeorbulina spp. below the FA of Orbulina suturalis defines Zone N8 (Blow, 1969). The interval from Sample $135-841 \mathrm{~B}-41 \mathrm{R}-1,72-76 \mathrm{~cm}$, to $-40 \mathrm{R}-\mathrm{CC}$ is referred here.

\section{Zone N9}

The presence of Orbulina suturalis below the FA of G. (Fohsella) peripheroacuta defines Zone N9. The interval from Sample 135-841B$40 \mathrm{R}-4,64-67 \mathrm{~cm}$, to $-32 \mathrm{R}-1,114-118 \mathrm{~cm}$, is referred to this zone.

\section{Zones N14 to N17A}

The rarity of planktonic foraminifers in Hole 841B above Sample $135-841 \mathrm{~B}-32 \mathrm{R}-1,114-118 \mathrm{~cm}$, makes it difficult to assign an accurate determination. The presence of $G$. (G.) nepenthes in Samples 135841B-29R-CC and 135-841B-20R-1, 104-107 cm, indicates an assignment to the N14 to N19-20 zonal interval. No evidence exists, from the resistivity and gamma-ray logs over the interval above the fault marking the boundary between Units III and IV, to suggest any stratigraphic break. For this reason there is little evidence to suggest an age assignment of older than Zone N16 for Unit III.

\section{Zone N17A}

Site 840 was the only site of Leg 135 to penetrate this zone definitely, as indicated by the presence of $G$. (G.) tumida plesiotumida below the FA of $P$. primalis. It is often difficult to distinguish between $G$. (G.) tumida plesiotumida and its ancestor, $G$. $(G$.) merotumida. Candeina nitida nitida is a readily identifiable species, which, according to both Blow (1969) and Kennett and Srinivasan (1983), first appears closely after $G$. (G.) tumida plesiotumida, making it an ideal marker for much of Zone N17A. At Site 840 C. nitida nitida ranges from the bottom of the hole. Though the upper boundary of Zone N17A is defined by the FA of $P$. primalis, Kennett and Srinivasan (1983) considered that the FAs of both $G$. (G.) multicamerata and $P$. 
primalis occur close together. However, in Site 840, the two events are separated by approximately $100 \mathrm{~m}$. A reason for this may be the difficulty of recognition of both species, as both are components of phylogenetic lineages. For this study, $G$. (G.) multicamerata is separated from its ancestral form, $G$. $(G$.) cultrata limbata, by having eight or more chambers in the final whorl. Similar difficulties exist for the differentiation of $P$. primalis from its ancestral form, Neogloboquadrina acostaensis. Another species considered to arise at a similar time is Globigerinoides conglobatus; this event occurs approximately $20 \mathrm{~m}$ below that of $G$. (G.) multicamerata in Site 840, suggesting that the FA of $P$. primalis may be unreliable in this area. For this reason the FA of $G$. (G.) multicamerata is here considered the most reliable and has been used to mark the base of Zone N17B in Site 840.

The FA of $G$. $(O$.$) margaritae, which Kennett and Srinivasan$ (1983) placed within Zone N19, was thought by Blow (1969) to have taken place within Zone N16; Berggren et al. (1985) dated this event at $5.6 \mathrm{Ma}$, a little earlier than that of $P$. primalis at $5.8 \mathrm{Ma}$, and so within the upper part of Zone N17A. At Site 840, G. (G.) margaritae first appears in Sample 135-840B-43X-3, 67-71 cm, below the FA of $G$. (G.) multicamerata, in agreement with Berggren et al. (1985).

\section{Zone N17B}

As noted above, the lower zonal boundary at Site 840 is defined by the FA of $G$. (G.) multicamerata. At this site, $P$. primalis first appears after a number of taxa, such as S. paenedehiscens, G. conglobatus, and $G$. (G.) multicamerata, which are normally considered to postdate this event (Kennett and Srinivasan, 1983). At Hole 841B the presence of Pulleniatina sp. in a thin section of Sample 135-841B20R-3, 66-69 cm, indicates Zone N17B or younger. Other samples from above this level suggest a level within Zone N16 or younger; for Sample 135-841B-19R-CC, this is based on the presence of $G$. kennetti; for Sample 135-841B-2R-CC, this is based on the presence of $G$. obliquus extremus. The presence of $G$. $(G$.) tumida plesiotumida in Sample 135-841A-10X-CC, and this subspecies with $G .(G$.) merotumida in Sample 135-841A-8X-CC indicates a level no higher than Zone N18.

\section{Zone N18}

Assemblages characteristic of Zone N18 were recovered from only Site 840 . As with the underlying Zone N17B, the distribution of $P$. primalis is rare and sporadic, and all populations of this species are dominated by sinistrally coiled forms. The FA of Neogloboquadrina humerosa, thought by Kennett and Srinivasan (1983) to be at the base of Zone N18, occurs $78 \mathrm{~m}$ below the FA of $G$. (G.) tumida tumida, suggesting that the FA of $N$. humerosa occurs within Zone N17B.

\section{Zones N19 and N19-20}

The boundary between Zones N19 and N19-20 is based on the FA of $G$. (T.) crassaformis crassaformis. At Site 840 this event occurs in the upper part of Core 135-840B-11X, at approximately $95 \mathrm{mbsf}$. Thus, the two zones can be recognized. However, Zone N19-20 is very thin, especially when compared with underlying Zone N18. According to Berggren et al. (1985), Zone N18 represents approximately $1 \mathrm{~m} . y$., whereas Zone $\mathrm{N} 19$ represents approximately $8 \mathrm{~m} . \mathrm{y}$. and Zone N19-20 approximately $12 \mathrm{Ma}$ (Fig. 2). Thus, both zones would appear to be separated by a substantial hiatus, spanning a large part of Zone N19-20. Generally, such a hiatus would be expected to be related to a stratigraphic or sedimentological change. Such a change, representing the boundary between Units I and II, occurs within the upper part of Core 135-840-12X, at 110 mbsf (Hawkins, Parson, Allan, et al., 1992), $15 \mathrm{~m}$ below the FA level of $G$. $(T)$ crassaformis crassaformis. Thus, the possibility exists that this event may be environmentally controlled, and that the base of Zone N19-20 coincides with the Unit I/II boundary. Support for this scenario also comes from the LA level of $G$. $(G$.) nepenthes, which occurs at the
Unit I/II boundary; this species overlaps with $G$. (T.) crassaformis crassaformis and occurs within Zone N19-20 (Berggren et al. 1985) (see Fig. 2).

Chaproniere (1985a), based on a study of dredge samples, suggested that the two seismic sequences that make up the upper part of the Tongan Platform recognized by Exon et al. (1985) and Herzer and Exon (1985) contained assemblages from the N17A to N19/20 zonal interval (the subdivision between Zones N19 and N19-20 was not recognized) and from Zones N21-N22, respectively. It is suggested here that Units I and II are the two units recognized by Exon et al. (1985) and Herzer and Exon (1985), and they are separated by a hiatus spanning part of Zone N19-20, that the lower seismic sequence ranges in age from at least Zone N17A to Zone N18; and that the upper seismic sequence ranges from Zone N19-20-N22 or younger. Nannofossil evidence suggests that the hiatus spans the interval from subzones $\mathrm{CN10c}$ to $\mathrm{CN11b}$ (Quinterno, this volume). According to Berggren et al. (1985), this zonal interval represents the topmost part of Zone N19 and much of Zone N19-20 (see Fig. 2).

At Site 834, Zones N19 and N19-20 are thicker than at Site 840. Examination of the distribution chart for Site 834 (Table 1) indicates a large number of barren samples over the interval covered by Zones $\mathrm{N} 18$ and N19, on account of the volcanic ash beds. Thus, no evidence is present for a missing section at Site 834 .

\section{Zone N21}

An interval where $G$. (T.) tosaensis is present without $G$. (T) truncatulinoides is found at Site 840 . At Site 840 this zone succeeds Zone N19-20. The FA of G. quadrilobatus fistulosus occurs at the same level, implying that perhaps the lower part of Zone N21, below the FA of $G$. quadrilobatus fistulosus is missing. However, as core recovery over this interval was poor (Hawkins, Parson, Allan, et al., 1992), the lack of samples may be a probable explanation for this occurrence.

\section{Zone N22}

As noted above, the faunal diversity at this site in the Pleistocene is lower than that of the Lau Basin sites. Nevertheless, some of the subzones of Zone N22, as recognized by Chaproniere (1991), have been recorded.

\section{Globigerinoides quadrilobatus fistulosus Subzone}

G. quadrilobatus fistulosus is very rare, being confined to two samples from Zone N21. The presence of G. obliquus extremus, which ranges only into the base of the $G$. (T.) crassaformis viola Subzone in the Lau Basin sites, similar to the occurrence as recorded by Berggren et al. (1985) and Chaproniere (1991). For this reason, the top of the G. quadrilobatus fistulosus Subzone has been tentatively placed at the LA of G. obliquus extremus at Site 840.

\section{Globorotalia (Truncorotalia) crassaformis viola Subzone}

Even though the FA of $G$. (T.) crassaformis hessi marks the upper boundary of the subzone, it is also characterized by the overlap of the ranges of $G$. (T.) tosaensis and $G$. (T.) truncatulinoides, above the LA of $G$. quadrilobatus fistulosus. Often $G$. (T) tosaensis overlaps the basal part of the range of $G$. (T.) crassaformis hessi (Chaproniere, 1991), but this overlap is not recorded at Site 840, and the two events are well separated, implying the involvement of environmental factors.

\section{Globorotalia (Truncorotalia) crassaformis hessi Subzone}

Though the $G$. (T.) crassaformis hessi Subzone was recognized, it is thin. This species is rare at this site, which is in common with the findings of Chaproniere (1985, in press). That this species is very rare on the southern Tongan Platform suggests that environmental factors influenced the distribution of this species making the lower boundary possibly biostratigraphically unreliable. 
Bolliella praeadamsi Subzone

B. praeadamsi is rare in this region, but its presence permits the subzone to be recognized at Site 840 .

\section{Zone N23}

No assemblages typical of Zone N23 were found at Site 840. This is probably best explained by loss of unconsolidated sediment during drilling operations.

\section{DISCUSSION}

\section{Results}

Reworked faunas were recorded only at Sites 834 and 835 . The former was located adjacent to the Lau Ridge, on which coral reefs and other shallow-water features are developed. It is to be expected that materials eroded from these features be redeposited into adjacent deep-water basins. Reworking is generally obvious as shallow-water benthic species and other bioclasts (such as coralline algae) are often accompanied by older planktonic species, mixed with younger species. Many are also iron-stained. Most of this reworking is confined to the upper part of the section, from within the Globorotalia (Truncorotalia) crassaformis viola Subzone and younger. At Site 835, reworking is less obvious as no accompanying displaced shallowwater benthic foraminifers and other bioclasts or iron-stained specimens are present. However, mixing of early Pleistocene and late Pliocene forms (e.g., Globigerinoides quadrilobatus fistulosus) with younger forms indicates that reworking has occurred. Site 835 was located in an isolated basin, cut off from most obvious sources for reworking. Seismic records over the site contain evidence for the presence of slumped sections within Site 835 (Hawkins, Parson, Allan, et al., 1992). Reworked faunas are present throughout the sequence above the Globorotalia (Truncorotalia) crassaformis hessi Subzone, being more intense over several intervals. This suggests that slumping of late Pliocene to early Pleistocene sediments exposed in the higher slopes of the basin has taken place continuously for most of the Pleistocene.

The absence of reworking at the remaining sites within the Lau Basin indicates that the small basins in which the various sites were located were sufficiently isolated from other areas, and that the only sediment sources were from volcanic eruptions and the planktonic layers of the water column. Such basins are ideal for testing the relationship between the various bioevents that have taken place throughout the Pleistocene. In contrast to the findings of Chaproniere (1991), most of the events were found in the same order as those recorded previously in more distant regions. The only exceptions are detailed in Chaproniere et al. (this volume). This suggests that many species in the Coral Sea region adjacent to the Great Barrier Reef were derived by erosion, probably during periods of low sea level, and then were redeposited in the troughs.

Evidence exists that not all of the bioevents used in this study are reliable, that is they may be diachronous. Dowsett (1989) and Hills and Thierstein (1989) found evidence that some planktonic foraminifer events in the Pliocene and Pleistocene were diachronous, especially over large areas, and between different climatic regimes. The FA of Globorotalia (Truncorotalia) truncatulinoides was one of the more important events found to be unreliable. However, as was pointed out by Chaproniere (1991), it is unlikely that such events would be diachronous within a single region, and so in this study they are still considered useful for correlation purposes within the subtropical to tropical western Pacific.

\section{Comparison with Previous Studies in the Lau Basin Area}

As noted above, the only biostratigraphic studies based on planktonic foraminifers in the Lau Ridge-Tongan Platform area were made by Kennett (1973), based on DSDP Site 208, Chaproniere (1985a,
$1985 \mathrm{~b}$, in press a, in press b) on dredge material, Hayward (1985) on dredge material and piston cores, and Daniels (1990) on a piston core.

Kennett (1973), using the zonal scheme of Blow (1969), recorded a continuous sequence from Zones N20 to N23. Because the sequence at DSDP Site 203 covered a more restricted biostratigraphic interval than that at other sites drilled during Leg 21, and because of the large number of volcanic ash beds, it received little attention in Kennett's study. The sequence from Site 203 is very similar to that recorded from the Lau Basin sites in this study, the major difference being that we have recognized Zones N19 and N19-20 in the region as defined by Kennett and Srinivasan (1983), because the original marker for Zone N20 ( N. pseudopima), as proposed by Blow (1969), proved to be unreliable by later studies (e.g., Brönnimann and Resig, 1971; Srinivasan and Kennett, 1981a, 1981b). As noted above, subsequent work has enabled us to subdivide Zones N22 and N23; because many of the biomarkers were not recognized at the time of Kennett's (1973) study, it is difficult to apply these subzones to the faunal assemblages identified from Site 203, even though they are almost certainly present at that site.

Chaproniere (1985a, in press b) has studied a large number of dredge samples from the Tongan Platform. From these he was able to build up a sequence similar to that found at Site 840 . He concluded that the middle seismic sequence of Exon et al. (1985) and Herzer and Exon (1985) ranged from Zones N17A to N19/20 (which is equivalent to the interval from Zones N19 to N19-20 as used here); the rarity of samples with a Zone N18 fauna was ascribed to the brief time span covered by this zone. The upper seismic sequence appeared to range from Zones N21 to N22 (Globorotalia (Truncorotalia) crassaformis hessi Subzone); the rarity of Zone N21 samples was thought to provide evidence for a hiatus covering part of this zonal interval. Evidence from Site 840 does not support the existence of a hiatus within Zone N21, but one may be present within the interval of Zone N19-20. Evidence from assemblages within clasts contained in the lower part of the middle seismic sequence, as exposed on the Tongan Platform, indicated that two other, older sequences were present in the subsurface: a late Eocene section unconformably overlain by an early Miocene section, as found in wells drilled on Tongatapu Island (Webb Tonga Inc., unpubl. data), and subsequently at Site 841 .

Chaproniere (in press a) reported on some samples dredged from the Lau Ridge and recorded Zone N3/4 (= Zone N4A in the scheme of Kennett and Srinivasan, 1983), Zone N17B, and Zones N22 and $\mathrm{N} 23$. This is a similar sequence to that found at Site 834 in the Lau Basin adjacent to the Lau Ridge; Zone N4A was not found and rocks of this age are probably restricted to the Lau Ridge.

As noted above, Hayward (1985) studied planktonic foraminifer faunas from the Lau Basin and the northern Tongan Platform, finding assemblages from Zones N21 and N23 in core-catcher samples from the central part of the Lau Basin that are of similar age to those recorded in this study. Dredge samples from the northern Tongan Platform contain assemblages assigned to Zone N19 and younger.

Daniels (1990) rccorded a Pleistocene sequence recovered in a piston core from the Lau Basin, southwest of Sites 838 and 839. Unfortunately, the species data given in that study make it difficult to apply the Pleistocene scheme used for Leg 135 on these assemblages. However, the record of $G$. (T.) crassaformis hessi without $G$. (T.) tosaensis suggests that the core bottomed in Zone N22 (Globorotalia (Truncorotalia) crassaformis hessi Subzone). The biostratigraphic range of pink forms of $G$. ruber is similar to that recorded in the Leg 135 Lau Basin sites, and the various subzones of Zone N23 probably would be recognizable if the assemblages were to be reexamined.

\section{AGE OF VOLCANICS AND BASALTIC BASEMENT}

Figure 5 clearly shows that a distinct variation is present in the age of the sediment directly overlying the seafloor basalts as well as the sedimentary beds interbedded within the volcanic sequences at some sites. 


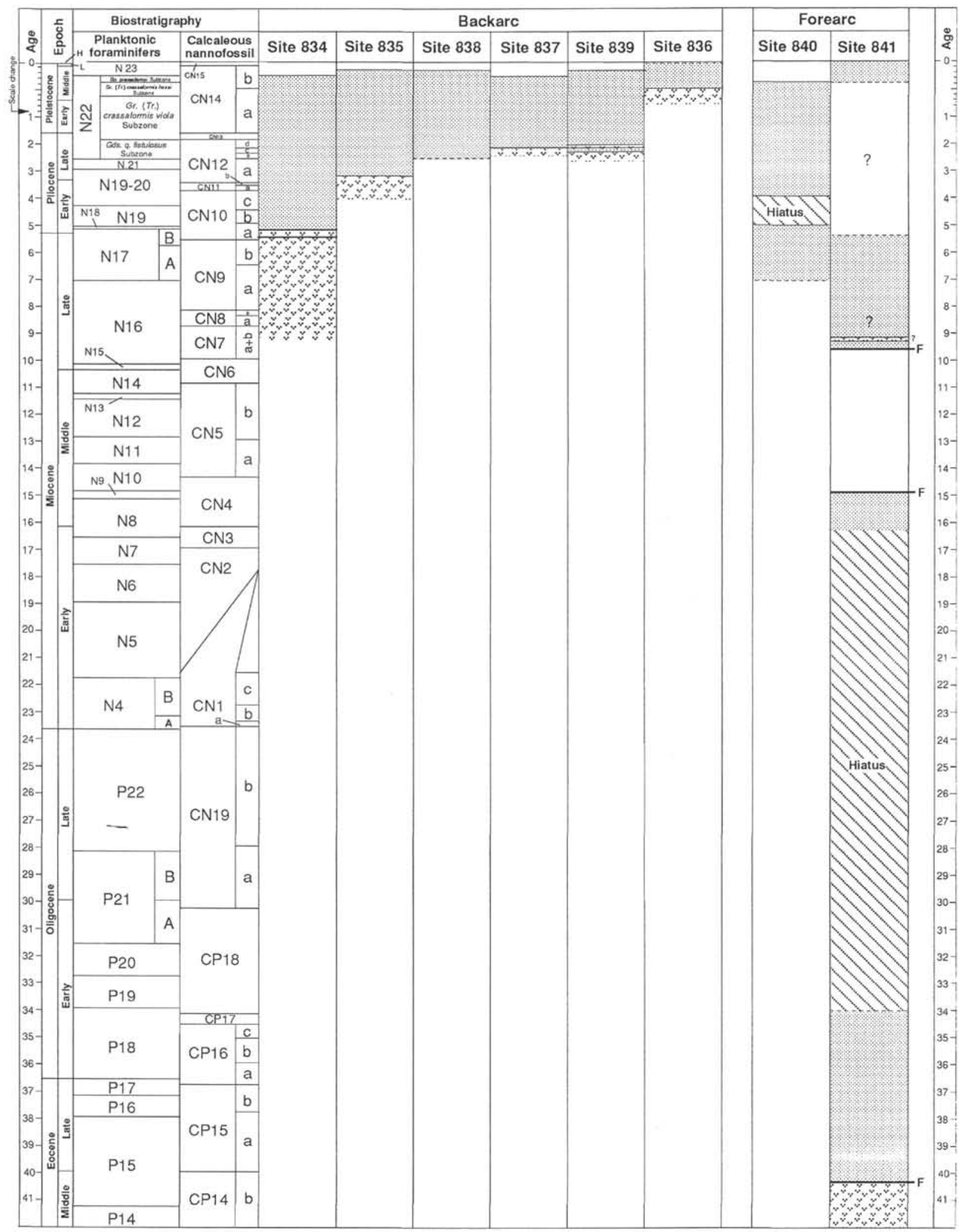

Figure 5. Summary of the age of igneous basement and overlying sediments for Sites 834 to 841 . Note that basement was not penetrated at Sites 838 and 840 . 
At Site 834 , the oldest sediments overlying basalt are typical of Zone N18. The sediments interbedded within the upper part of the basalt section were also deposited in this zonal interval, but some of the lower beds contain a typical Zone N17B assemblage. Thus, the age of the upper basalts is constrained to the Zone N17B and Zone N18 interval.

At Site 835, no sediments were found within the basalts, but the overlying sediments contain a Zone N19-20 assemblage. The thin sequence containing this fauna suggests that only the upper part of Zone N19-20 is represented. Thus, the basalts at this site can be no younger than the upper part of Zone N19-20.

At Sites 837 and 839, basalts were overlain by sediments from Zone N22 (Globigerinoides quadrilobatus fistulosus Subzone). At Site 839 sediments from this same subzone are interbedded within the upper part of the volcanics. This evidence indicates that the basalts can be no younger than basal Zone N22, and that at Site 839 , basalts were extruded within the Globigerinoides quadrilobatus fistulosus Subzone. No basalts were encountered at Site 838, but the sediments at the bottom of the hole were from the same subzone.

At Site 836, Zone N22 (Globorotalia (Truncorotalia) crassaformis hessi Subzone) sediments both overlie and are interbedded with the basaltic sequence, constraining the age of the basalts at this site to this subzone.

These results indicate that there is a distinct trend from older to younger basaltic extrusions from the Lau Ridge toward the center of the Lau Basin.

At all sites from the Lau Basin, Unit I marks a distinct decrease in the thickness and frequency of ash beds, which marks a decline in volcanicity in the region (Fig. 3). This decline, however, does not appear to be isochronous throughout the basin. At Sites 834 and 835 the base of Unit I contains an assemblage typical of Zone N22 (Globigerinoides quadrilobatus fistulosus Subzone). At Sites 836, 837 , and 838, the base of the unit is within Zone N22 (Globorotalia (Truncorotalia) crassaformis hessi Subzone) and for Site 839 it is within the Zone N22 (Bolliella praeadamsi Subzone). Thus, the trend is for the age of the decrease in volcanism to become younger toward the center of the Lau Basin. A second observation is that the thickness of Unit I is considerably greater at Sites 834 and 835, where a large amount of reworking has taken place; at Site 834 from the adjacent Lau Ridge, and at Site 835 from slumping of the basin walls.

Biostratigraphic resolution for the Tongan Platform sites was such that it was not possible to make observations concerning the timing or decline in volcanic activity observed in the Lau Basin sites.

\section{CONCLUSIONS}

Most of the bioevents were found to occur in a similar order to those recorded in most zonal schemes. This suggests that most are reliable for correlation purposes, even if some (e.g., the FA of Globorotalia (Truncorotalia) truncatulinoides) are known to be diachronous. However, as was pointed out by Chaproniere (1991), it is unlikely that such events would be diachronous within a single region, and so in this study they are considered to be reliable within the geographic region studied here.

The occurrences of some biostratigraphically important species such as Globigerinoides quadrilobatus fistulosus, Globorotalia (Truncorotalia) crassaformis hessi, Pulleniatina finalis, and $P$. primalis are sporadic, suggesting some environmental influences (such as temperature or water mass properties) on their distribution.

Reworked planktonic foraminifers were recorded from only Sites 834 and 835 . Site 834 contains fauna and floral elements clearly sourced from a late Pliocene, shallow-water environment, whereas those at Site 835 are restricted to a single source and were slumped into the basin. No evidence was present for reworking at the remaining Lau Basin sites, indicating that the source for the fossils was localized.

Site 834 penetrated through a Quaternary, Pliocene sequence overlying basaltic basement, and topmost Miocene (Zone N17B) sediments interbedded within the volcanic sequence. Site 835 penetrated into the early Pliocene (Zones N19 to N19-20). Site 836 penetrated the shortest section, with Zone N22 (Globorotalia (Truncorotalia) crassaformis hessi Subzone) directly overlying basalts. Site 837 penetrated into the basal part of Zone N22 (Globigerinoides fistulosus Subzone) overlying basalt. Site 838 failed to encounter basalts, with the oldest sediment being from Zone N22 (Globigerinoides fistulosus Subzone). Site 839, within the same basin as Site 838, located Zone N22 (Globigerinoides fistulosus Subzone) sediments directly overlying igneous basement. The oldest sediments in the Lau Basin sites are from Zone N17B, within and overlying the basalt sequence. This indicates that the Lau Basin began before 5.2 Ma.

The decline in volcaniclastic materials that marks Unit I in most Lau Basin Sites varies from the lower part of Zone N22 (Globigerinoides quadrilobatus fistulosus Subzone) to the upper part of Zone N22 (Bolliella praeadamsi Subzone). This indicates volcaniclastic sources were localized to each of the smaller basins within the Lau Basin.

The oldest sediments in Site 840 on the Tonga Ridge are from Zone N17A. A hiatus may exist within the N19 to N19-20 zonal interval at this site at approximately 110 mbsf, suggesting that Reflector A, which is thought to be at approximately $383 \mathrm{mbsf}$, is based on a physical property change corresponding to a zone of sediment alteration (Hawkins, Parson, Allan, et al., 1992), and not on a break in sedimentation.

It is suggested here that Units I and II are the two units recognized by Exon et al. (1985) and Herzer and Exon (1985) and that they are separated by a hiatus spanning part of Zone N19-20, that the lower seismic sequence ranges in age from at least Zones N17A to N18, and that the upper seismic sequence ranges from Zone N19-20 to N22 or younger.

At Site 841 , the upper Miocene to Holocene sequence (Zones $\mathrm{N} 17-\mathrm{N} 23$ ) is mainly barren of calcareous microfossils, with rare, low-diversity assemblages recovered from some levels. This paucity of faunas is a result of the site having been below the CCD throughout this time. This poorly fossiliferous sequence is faulted against a middle Miocene unit (Zones N8-N9), which contains a diverse faunal assemblage and must have been deposited above the CCD.

Site 841 subsided rapidly over the interval from Zones N9 to N17.

\section{ACKNOWLEDGMENTS}

The authors are deeply indebted to K. Mukaiyama, R. Chinone, M. Tamura, A. Kurosawa, and T. Sato, Department of Earth Sciences, Yamagata University, for their help with SEM photography and preparation of the plates. G.C. Chaproniere publishes with the permission of the Executive Director, Australian Geological Survey Organisation, Canberra.

\section{REFERENCES}

Berggren, W.A., Kent, D.V., and Van Couvering, J.A., 1985. The Neogene: Part 2. Neogene geochronology and chronostratigraphy. In Snelling, N.J. (Ed.), The Chronology of the Geological Record. Geol. Soc. London Mem., 10:211-260.

Blow, W.H., 1969. Late middle Eocene to Recent planktonic foraminiferal biostratigraphy. In Brönniman, P., and Renz, H.H. (Eds.), Proc. First Int. Conf. Planktonic Microfossils, Geneva, 1967: Leiden (E.J. Brill), 1:199-422.

Bolli, H.M., and Premoli-Silva, I., 1973. Oligocene to Recent planktonic foraminifera and stratigraphy of the Leg 15 Sites in the Caribbean Sea. In Edgar, N.T., Saunders, J.B., et al., Init. Repts. DSDP, 15: Washington (U.S. Govt. Printing Office), 475-497.

Brönnimann, P., and Resig, J., 1971. A Neogene globigerinacean biochronologic timescale of the Southwestern Pacific. In Winterer, E.L., Riedel,

\footnotetext{
Abbreviations for names of organizations and publication titles in ODP reference lists follow the style given in Chemical Abstracts Service Source Index (published by American Chemical Society).
} 
W.R., et al., Init. Repts. DSDP, 7 (Pt. 2): Washington (U.S. Govt. Printing Office), 1235-1469.

Chaproniere, G.C.H., 1985a. Late Neogene and Quaternary planktonic foraminiferal biostratigraphy and paleobathymetry of dredge samples from the southern Tongan Platform (Cruise L5-82-SP). In Scholl, D.W., and Vallier, D.L. (Eds.), Geology and Offshore Resources of Pacific Island ArcsTonga Region. Circum-Pac. Counc. Energy Min. Resour., Earth Sci. Ser., 2:131-140.

, 1985b. Late Tertiary and Quaternary foraminiferal biostratigraphy and paleobathymetry of cores and dredge samples from Cruise KK820316 Leg 2. In Brocher, T.M. (Ed.), Geological Investigations of the Northern Melanesian Borderland. Circum-Pac. Counc. Energy Min. Resour., Earth Sci. Ser., 3:103-122.

1991. Pleistocene to Holocene planktic foraminiferal biostratigraphy of the Coral Sea, offshore Queensland, Australia. BMR J. Aust. Geol. Geophys., 12:195-221.

, in press a. Late Eocene to Pleistocene foraminiferal biostratigraphy and paleobathymetry of dredge samples from the southern Tongan Platform (Cruise L3-84-SP). In Ballance, P.F., et al. (Eds.), Contributions to the Geology of the Tonga and Lau Regions of the Southwest Pacific. Circum-Pac. Counc. Energy Min. Resour., Earth Sci. Ser.

_ in press b. Late Oligocene, late Miocene and Pleistocene foraminiferal biostratigraphy and paleobathymetry of dredge samples from the Lau Ridge (Cruise L3-84-SP). In Ballance, P.F., Stevenson, A., and Herzer, R. (Eds.), Contributions to the Geology of the Tonga and Lau Regions of the Southwest Pacific. Circum-Pac. Counc. Energy Min. Resour., Earth Sci. Ser.

Daniels, C.H., 1990. Foraminifera and oxygen isotope stratigraphy in a core from the Lau Basin, southwest Pacific. Geol. Jahrb., D92:209-229.

Dowsett, H.J., 1989. Application of the graphic correlation method to Pliocene marine sequences. Mar. Micropaleontol., 14:3-32.

Exon, N.F., Herzer, R.H., and Cole, J., 1985. Mixed volcaniclastic and pelagic sedimentary rocks from the Cenozoic southern Tonga platform and their implications for petroleum potential. In Scholl, D.W., and Vallier, T.L. (Eds.), Geology and Offshore Resources of Pacific Island Arcs-Tonga Region. Circum-Pac. Counc. Energy Miner. Resour., Earth Sci. Ser., 2:75-107.

Hayward, B.W., 1985. Foraminiferal micropaleontology of samples from northern Tonga. In Honza, E., Lewis, K.B., and Shipboard Party (Eds.), A Marine Geological Survey of the Northern Tonga Ridge and Adjacent Lau Basin. Min. Resour. Tonga, Field Rep., 1:99-101.

Herzer, R.H., and Exon, N.F., 1985. Structure and basin analysis of the southern Tonga forearc. In Scholl, D.W., and Vallier, T.L. (Eds.), Geology and Offshore Resources of Pacific Island Arcs-Tonga Region. CircumPac. Counc. Energy Miner. Resour., Earth Sci. Ser., 2:55-73.

Hills, S.J., and Thierstein, H.R., 1989. Plio-Pleistocene calcareous plankton biochronology. Mar. Micropaleontol., 14:67-96.

Kennett, J.P., 1973. Middle and late Cenozoic planktonic foraminiferal biostratigraphy of the Southwest Pacific, DSDP Leg 21. In Burns, R.E., Andrews, J.E., et al., Init. Repts. DSDP, 21: Washington (U.S. Govt. Printing Office), 575-639.

Kennett, J.P., and Srinivasan, M.S., 1983. Neogene Planktonic Foraminifera: A Phylogenetic Atlas: Stroudsburg, PA (Hutchinson Ross).

Parson, L., Hawkins, J., Allan, J., et al., 1992. Proc. ODP, Init. Repts., 135: College Station, TX (Ocean Drilling Program).

Srinivasan, M.S., and Kennett, J.P., 1981a. Neogene planktonic foraminiferal biostratigraphy and evolution: equatorial to subantarctic, South Pacific. Mar. Micropaleontol., 6:499-533.

1981b. A review of Neogene planktonic foraminiferal biostratigraphy: applications in the equatorial and south Pacific. Spec. Publ.-Soc. Econ. Paleontol. Mineral., 32:395-432.

Stainforth, R.M., Lamb, J.L., Luterbacher, H.P., Beard, J.H., and Jeffords, R.M., 1975. Cenozoic planktonic foraminiferal zonation and characteristics of index forms. Univ. Kans. Paleontol. Contrib. Art., 62:1-425.

\section{Date of initial receipt: 1 September 1992 \\ Date of acceptance: 3 December 1992 \\ Ms 135SR-117}

\section{LIST OF PLANKTONIC FORAMINIFERS}

"Tinophodella" evoluta Fordham, 1986 (PI. 1, Figs. 25-27) Bolliella adamsi Banner and Blow, 1959

Bolliella calida calida (Parker, 1962) (PI. 1, Figs. 1-3)
Bolliella calida praecalida (Blow, 1969) (Pl. 1, Figs. 4-6, 16-18)

Bolliella praeadamsi Chaproniere, 1991 (Pl. 1, Figs. 10-12)

Candeina nitida nitida d'Orbigny, 1839

Dentoglobigerina altispira altispira (Cushman and Jarvis, 1936) (Pl. 4, Figs. 28-30)

Dentoglobigerina altispira globosa (Bolli, 1957)

Dentoglobigerina baroemoenensis (LeRoy, 1939)

Dentoglobigerina conglomerata (Schwager, 1866)

Dentoglobigerina venezuelana (Hedberg, 1937)

Globigerina (Beella) digitata digitata (Brady, 1879) (Pl. 1, Figs. 7-9)

Globigerina (Beella) digitata praedigitata Parker, 1967

Globigerina (Globigerina) angustiumbilicata Bolli, 1957

Globigerina (Globigerina) bulloides bulloides d'Orbigny, 1826

Globigerina (Globigerina) bulloides umbilicata Orr and Zaitzeff, 1971

Globigerina (Globigerina) falconensis Blow, 1959

Globigerina (Globigerina) foliata Bolli, 1957

Globigerina (Globigerina) incisa Brönnimann and Resig, 1971

Globigerina (Globigerina) polypetala Fordham, 1986

Globigerina (Globigerina) praebulloides Blow, 1959

Globigerina (Globigerina) quinqueloba Natland, 1938

Globigerina (Globoturborotalita) apertura Cushman, 1918

Globigerina (Globoturborotalita) decoraperta Takayanagi and Saito, 1962 (Pl. 3, Figs. 28-30)

Globigerina (Globoturborotalita) druryi Akers, 1955

Globigerina (Globoturborotalita) nepenthes nepenthes Todd, 1957

Globigerina (Globoturborotalita) nepenthes picassiana Perconig, 1968

Globigerina (Globoturborotalita) nepenthoides Brönnimann and Resig, 1971

Globigerina (Globoturborotalita) rubescens rubescens Hofker, 1956 (PI. 4, Figs. 1-3)

Globigerina (Globoturborotalita) rubescens tenellus (Parker, 1958) (PI. 4, Figs. 4-6)

Globigerina (Globoturborotalita) woodi woodi Jenkins, 1960

Globigerinella aequilateralis (Brady, 1879) (Pl. 1, Figs. 13-15)

Globigerinella obesa (Bolli, 1957)

Globigerinita glutinata glutinata (Egger, 1893)

Globigerinita glutinata naparimaensis Brönnimann, 1951

Globigerinita glutinata parkerae (Bermudez, 1961)

Globigerinoides conglobatus (Brady, 1879) (Pl. 4, Figs. 22-24)

Globigerinoides diminutus Bolli, 1957

Globigerinoides elongatus (d'Orbigny, 1826)

Globigerinoides kennetti Keller and Poore, 1980

Globigerinoides mitra Todd, 1956

Globigerinoides obliquus extremus Bolli and Bermudez, 1965 (PI. 4, Figs. 16-21)

Globigerinoides obliquus obliquus Bolli, 1957

Globigerinoides parawoodi Keller, 1981

Globigerinoides quadrilobatus fistulosus (Schubert, 1910) (Pl. 4, Figs. 25-27)

Globigerinoides quadrilobatus sacculifer (Brady, 1877)

Globigerinoides ruber (d'Orbigny, 1839)

Globoquadrina dehiscens dehiscens (Chapman, Parr, and Collins, 1934)

Globorotalia (Fohsella) peripheroronda Blow and Banner, 1966

Globorotalia (Globoconella) conomiozea Kennett, 1966

Globorotalia (Globoconella) inflata (d'Orbigny, 1839) (PI. 3, Figs. 1-3)

Globorotalia (Globoconella) miotumida conoidea Walters, 1955

Globorotalia (Globoconella) puncticulata (Deshayes, 1832)

Globorotalia (Globoconella) sphericomiozea Walters, 1965

Globorotalia (Globoconella) triangula Theyer, 1973

Globorotalia (Globorotalia) archeomenardii Bolli, 1957

Globorotalia (Globorotalia) cultrata cultrata (d'Orbigny, 1839) (PI. 2, Figs. 7-9)

Globorotalia (Globorotalia) cultrata fimbriata (Brady, 1884)

Globorotalia (Globorotalia) cultrata limbata (Fomasini, 1902)

Globorotalia (Globorotalia) cultrata menardii (Parker, Jones and Brady, 1865) (PI. 2, Figs. 13-15)

Globorotalia (Globorotalia) cultrata neoflexuosa Srinivasan, Kennett, and Bé, 1974 (PI. 2, Figs. 10-12)

Globorotalia (Globorotalia) lenguaensis Bolli, 1957 (Pl. 4, Figs. 13-15)

Globorotalia (Globorotalia) merotumida Blow and Banner, 1965

Globorotalia (Globorotalia) multicamerata Cushman and Jarvis, 1930 (PI. 2, Figs. 4-6)

Globorotalia (Globorotalia) paralenguaensis Blow, 1969 (Pl. 4, Figs, 10-12) 
Globorotalia (Globorotalia) tumida flexuosa (Koch, 1923)

Globorotalia (Globorotalia) tumida plesiotumida Blow and Banner, 1965 (PI. 4, Figs. 7-9)

Globorotalia (Globorotalia) tumida tumida (Brady, 1877)

Globorotalia (Globorotalia) ungulata Bermudez, 1960 (Pl. 2, Figs. 1-3)

Globorotalia (Obandyella) bermudezi Rögl and Bolli, 1973 (Pl. 1, Figs. 28-30)

Globorotalia (Obandyella) cibaoensis Bermudez, 1949

Globorotalia (Obandyella) hirsuta hirsuta (d'Orbigny, 1839)

Globorotalia (Obandyella) hirsuta praehirsuta Blow, 1969

Globorotalia (Obandyella) juanai Bermudez and Bolli, 1969

Globorotalia (Obandyella) margaritae Bolli and Bermudez, 1965

Globorotalia (Obandyella) scitula scitula (Brady, 1882)

Globorotalia (Obandyella) theyeri Fleisher, 1970

Globorotalia (Truncorotalia) crassaformis crassaformis (Galloway and Wissler, 1927) (Pl. 2, Figs. 25-27)

Globorotalia (Truncorotalia) crassaformis hessi Bolli and Premoli Silva, 1974 (Pl. 3, Figs. 7-9)

Globorotalia (Truncorotalia) crassaformis ronda Blow, 1969 (Pl. 3, Figs. 4-6)

Globorotalia (Truncorotalia) crassaformis viola Blow, 1969 (Pl. 3, Figs. 10-12)

Globorotalia (Truncorotalia) crassula Cushman and Stewart, 1930 (Pl. 3 , Figs. 13-15)

Globorotalia (Truncorotalia) tosaensis Takayanagi and Saito, 1962 (Pl. 2 , Figs. 22-24)

Globorotalia (Truncorotalia) truncatulinoides (d'Orbigny, 1839) (Pl. 2. Figs. 16-21)

Globorotaloides hexagona (Natland, 1938)

Globorotaloides variabilis Bolli, 1957

Hastigerina pelagica (d'Orbigny, 1839)

Neoacarinina blowi Thompson, 1973
Neogloboquadrina acostaensis Blow, 1959

Neogloboquadrina continuosa (Blow, 1959)

Neogloboquadrina dutertrei (d'Orbigny, 1830)

Neogloboquadrina humerosa (Takayanagi and Saito, 1962)

Neogloboquadrina pachyderma (Ehrenberg, 1861)

Neogloboquadrina pseudopima (Blow, 1969)

Orbulina suturalis Brönnimann, 1951

Orbulina universa d'Orbigny, 1839

Orbulina universa bilobate form d'Orbigny, 1839

Orbulina universa trilobate form d'Orbigny, 1839

Paragloborotalia acrostoma (Wezel, 1966)

Paragloborotalia nana (Bolli, 1957)

Praeorbulina glomerosa circularis Blow, 1956

Praeorbulina glomerosa curva Blow, 1956

Praeorbulina glomerosa glomerosa Blow, 1956

Pulleniatina finalis Banner and Blow, 1967 (Pl. 3, Figs. 16-18)

Pulleniatina obliquiloculata (Parker and Jones, 1865) (Pl. 3, Figs. 22-24)

Pulleniatina praecursor Banner and Blow, 1967 (PI. 3, Figs. 19-21)

Pulleniatina primalis Banner and Blow, 1967

Pulleniatina spectabilis Parker, 1965

Sphaeroidinella dehiscens dehiscens (Parker and Jones, 1865)

Sphaeroidinella dehiscens excavata Banner and Blow, 1965

Sphaeroidinellopsis paenedehiscens Blow, 1969 (Pl. 3, Figs. 25-27)

Sphaeroidinellopsis seminulina kochi (Caudri, 1934)

Sphaeroidinellopsis seminulina seminulina (Schwager, 1866)

Streptochilus globigerum (Schwager, 1866)

Streptochilus tokelauae (Boersma, 1969)

Tenuitella anfracta (Parker, 1967) (Pl. 1, Figs. 19-21)

Tenuitella clemenciae (Bermudez, 1961)

Tenuitella fleisheri Li Qianyu, 1987 (Pl. 1, Figs. 22-24)

Tenuitella iota (Parker, 1962)

Turborotalita humilis (Brady, 1884) 


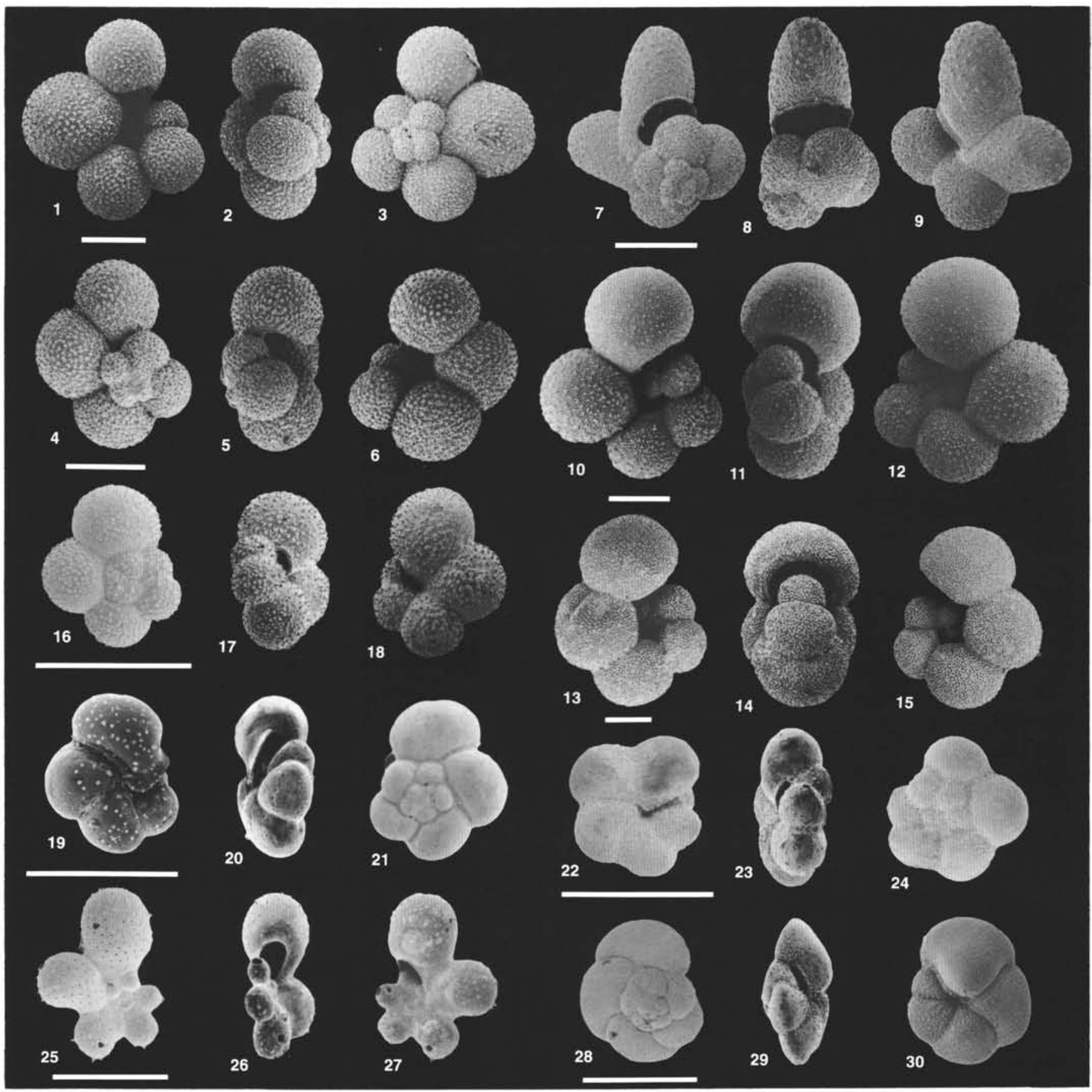

Plate 1. Scale bar represents $200 \mu \mathrm{m}$. All specimens are illustrated from the spiral, umbilical, and side views. 1-3. Bolliella calida calida, Sample 135-836A-1H-1, 12-17 cm, CPC30890. 4-6. Bolliella calida praecalida, Sample 135-836A-1H-1, 12-17 cm, CPC30891. 7-9. Globigerina (Beella) digitata digitata, Sample 135-836A-2H-3,53-58 cm, CPC30892. 10-12. Bolliella praeadamsi, Sample 135-836A-1H-1, 12-17 cm, CPC30893. 13-15. Globigerinella aequilateralis, Sample 135-836A-1H-1, 12-17 cm, CPC30894. 16-18. Tenuitella iota, Sample 135-836A-1H-1, 78-83 cm, CPC30895. 19-21. Tenuitella anfracta, Sample 135-836A-1H-1, 78-83 cm, CPC30896. 22-24. Tenuitella fleisheri, Sample 135-836A-1H-1, 78-83 cm, CPC30897. 25-27. "Tinophodella" evoluta, Sample 135-836A-1H-1, 78-83 cm, CPC30898. 28-30. Globorotalia (Obandyella) bermudezi, Sample 135-838A-8H-5, 50-55 cm, CPC30899. 


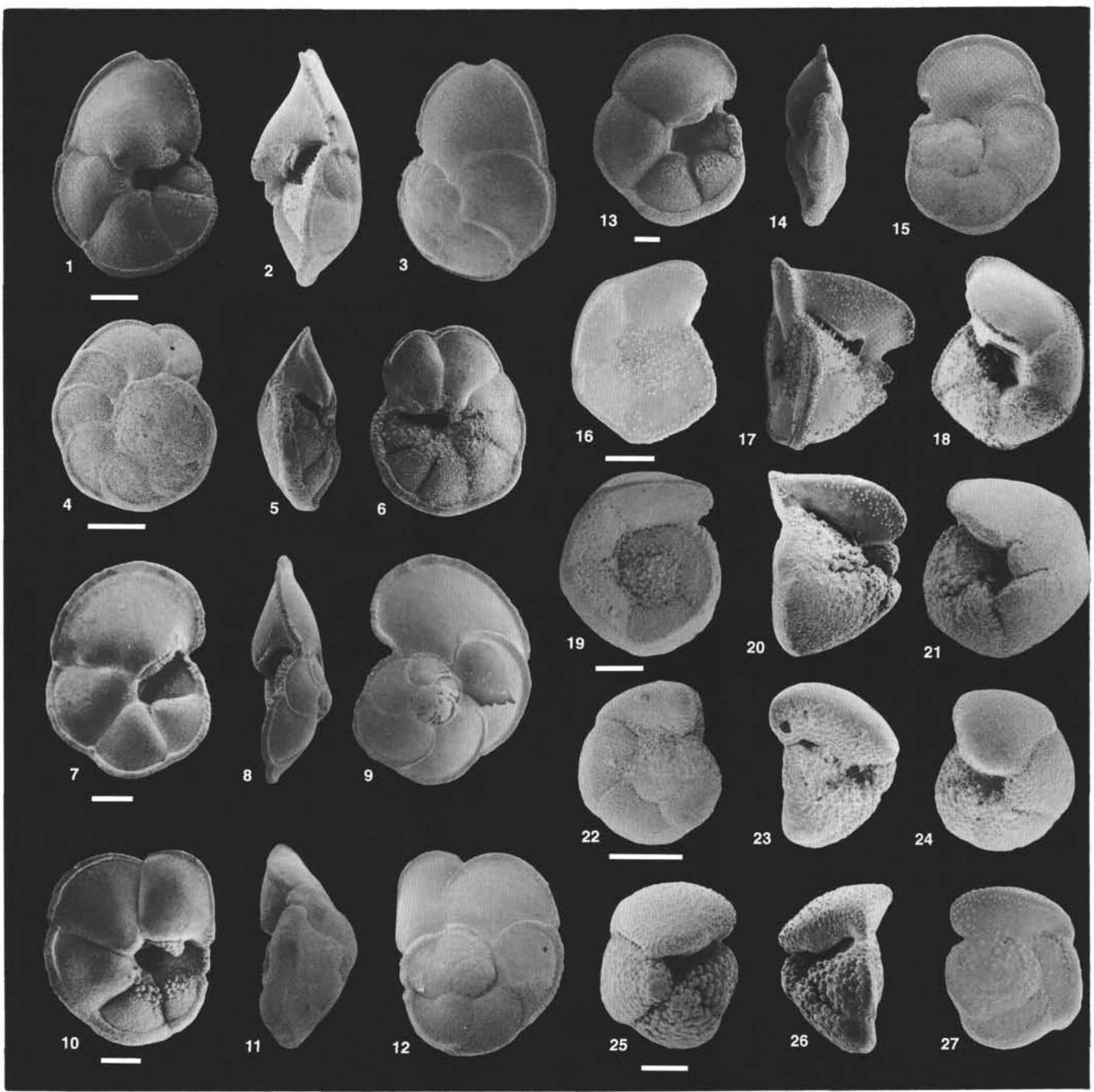

Plate 2. Scale bar represents $200 \mu \mathrm{m}$. All specimens are illustrated from the spiral, umbilical, and side views. 1-3. Globorotalia (Globorotalia) ungulata, Sample 135-838A-1H-CC, CPC30900. 4-6. Globorotalia (Globorotalia) multicamerata, Sample 135-838B-11R-1, 17-21 cm, CPC30901. 7-9. Globorotalia (Globorotalia) cultrata cultrata, Sample 135-836A-2H-3,53-58 cm, CPC30902. 10-12. Globorotalia (Globorotalia) cultrata neoflexuosa, Sample 135-836A2H-6, 46-51 cm, CPC30903. 13-15. Globorotalia (Globorotalia) cultrata menardii, Sample 135-836A-2H-3, 53-58 cm, CPC30904. 16-18. Globorotalia (Truncorotalia) truncatulinoides (specimen with a high umbilical side), Sample 135-838A-1H-CC, CPC30905. 19-21. Globorotalia (Truncorotalia) truncatulinoides, Sample 135-836A-2H-3, 53-58 cm, CPC30906. 22-24. Globorotalia (Truncorotalia) tosaensis, Sample 135-835A-16H-2, 103-109 cm, CPC30907. 25-27. Globorotalia (Truncorotalia) crassaformis crassaformis, Sample 135-836A-1H-1, 12-17 cm, CPC30908. 


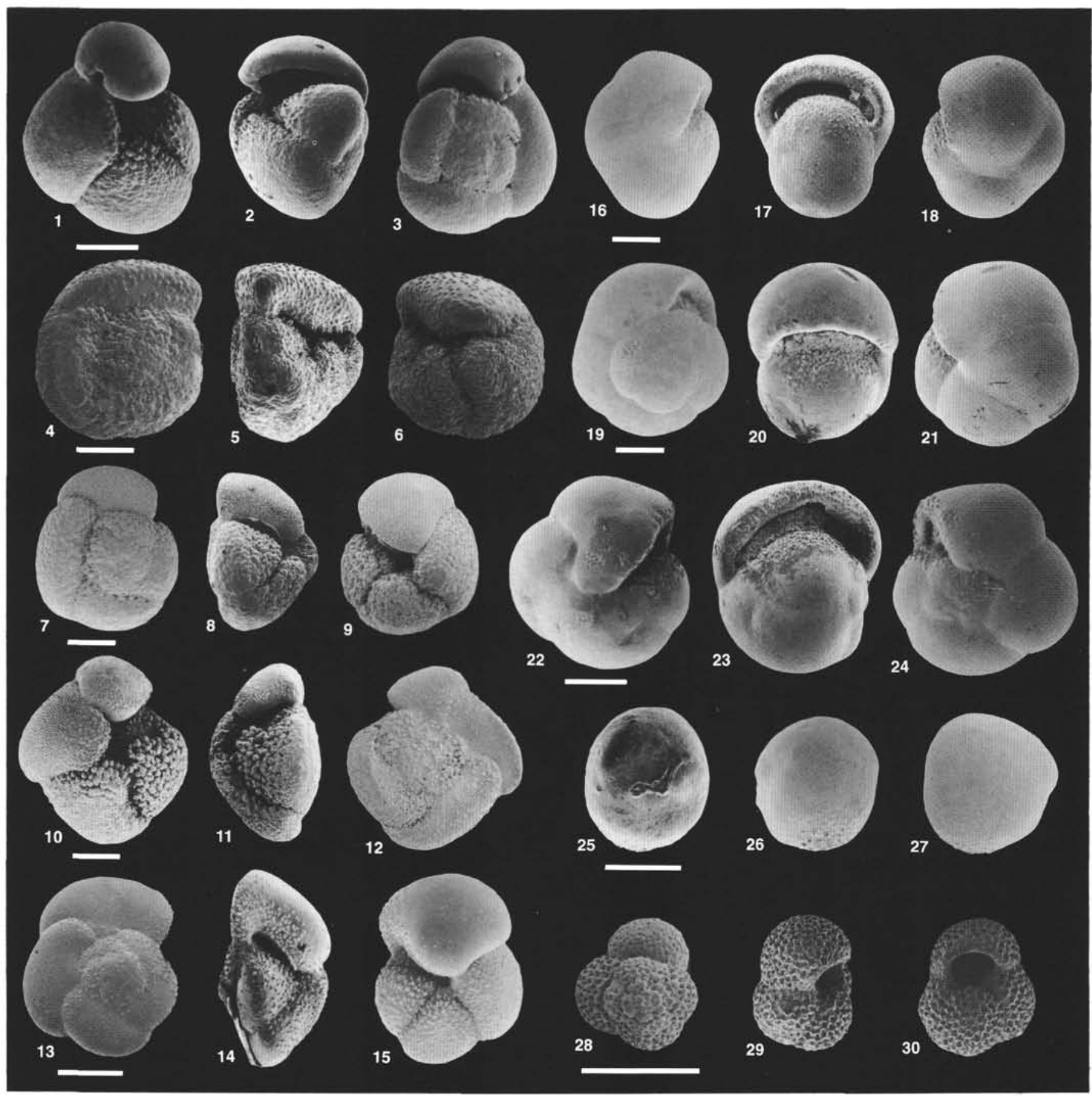

Plate 3. Scale bar represents $200 \mu \mathrm{m}$. All specimens are illustrated from the spiral, umbilical, and side views. 1-3. Globorotalia (Globoconella) inflata, Sample 135-836A-2H-3, 53-58 cm, CPC30909. 4-6. Globorotalia (Truncorotalia) crassaformis ronda, Sample 135-836A-2H-3, 53-58 cm, CPC30910. 7-9. Globorotalia (Truncorotalia) crassaformis hessi, Sample 135-836A-2H-3, 53-58 cm, CPC30911. 10-12. Globorotalia (Truncorotalia) crassaformis viola, Sample 135-838A-1H-1, 32-36 cm, CPC30912. 13-15. Globorotalia (Truncorotalia) crassula, Sample 135-836A-1H-1, 12-17 cm, CPC30913. 16-18. Pulleniatina finalis, Sample 135-836A-3H-1,92-96 cm, CPC30914. 19-21. Pulleniatina praecursor, Sample 135-835A-9H-7, 49-54 cm, CPC30915. 22-24. Pulleniatina obliquiloculata, Sample 135-835A-9H-7,49-54 cm, CPC30916. 25-27. Sphaeroidinellopsis paenedehiscens (specimen from within Zone N22, Globigerinoides quadrilobatus fistulosus Subzone), Sample 135-838B-11R-1, 14-17 cm, CPC30917. 28-30. Globigerina (Globoturborotalita) decoraperta, Sample 135-837A$6 \mathrm{H}-6,97-102 \mathrm{~cm}, \mathrm{CPC} 30918$. 


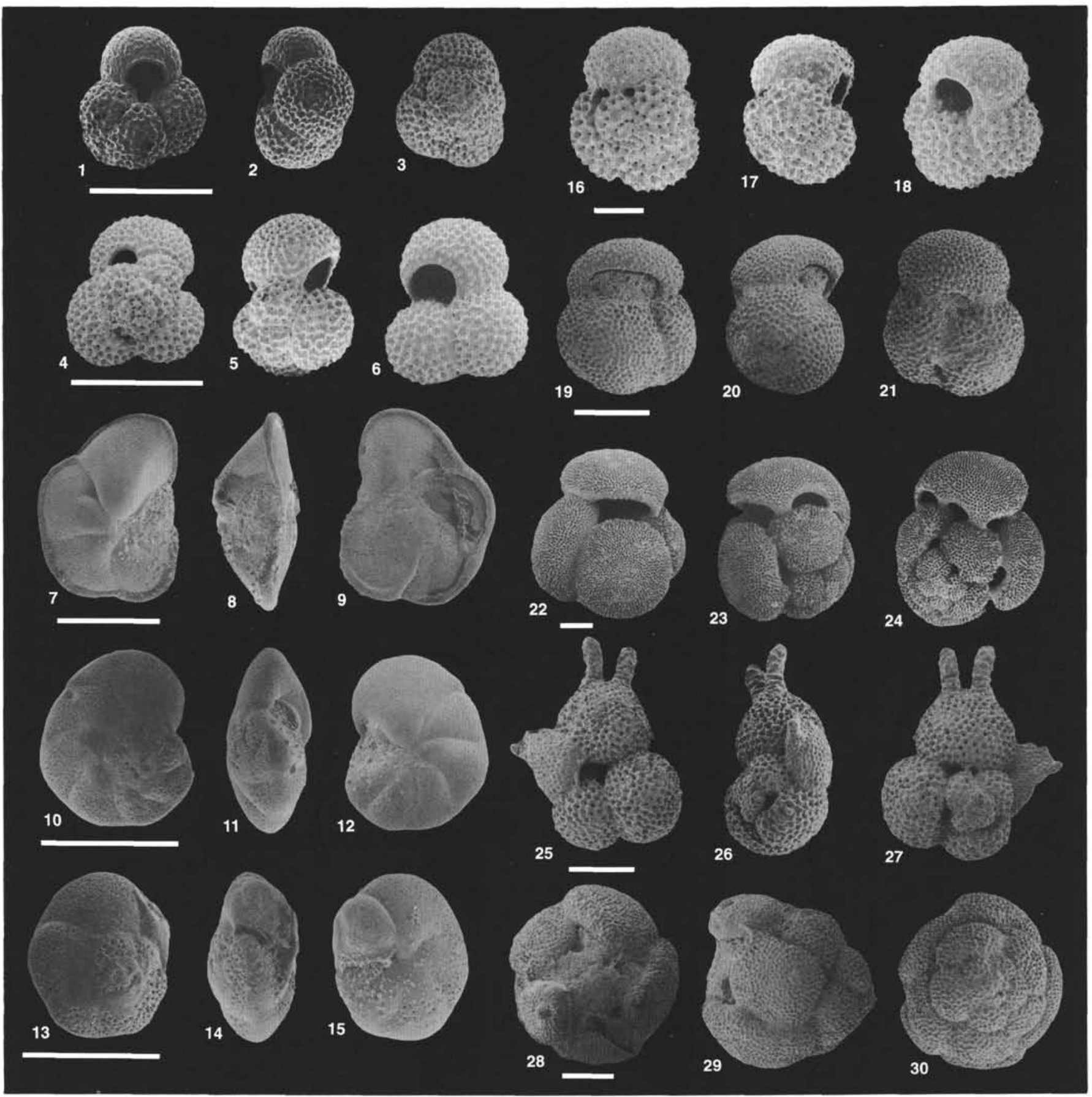

Plate 4. Scale bar represents $200 \mu \mathrm{m}$. All specimens are illustrated from the spiral, umbilical, and side views. 1-3. Globigerina (Globoturborotalita) rubescens rubescens, Sample 135-836A-2H-6, 46-51 cm, CPC30919. 4-6. Globigerina (Globoturborotalita) rubescens tenellus (note the two spiral apertures), Sample 135-836A-3H-1, 92-96 cm, CPC30920. 7-9. Globorotalia (Globorotalia) tumida plesiotumida, Sample 135-840B-28X-1, 85-87 cm. 10-12. Globorotalia (Globorotalia) paralenguaensis, Sample 135-840B-28X-1, 85-87 cm. 13-15. Globorotalia (Globorotalia) lenguaensis, Sample 135-840B-28X-1, 85-87 cm. 16-18. Globigerinoides obliquus extremus (the highest occurrence of this form at this site), Sample 135-838A-3H-2, 44-49 cm, CPC30921. 19-21. Globigerinoides obliquus obliquus, Sample 135-840A-3H-2, $44-49 \mathrm{~cm}$. 22-24. Globigerinoides conglobatus, Sample 135-835B-1R-CC. 25-27. Globigerinoides quadrilobatus fistulosus, Sample 135-835A-15H-2, 33-38 cm. 28-30. Dentoglobigerina altispira altispira, Sample 135-840B-28X-1, 104-106 cm. 